\title{
An Examination of the Impacts of the WVU Research Apprenticeship Program (RAP)
}

\author{
Mostafa Hashemi \\ West Virginia University, mohashemi@mix.wvu.edu
}

Follow this and additional works at: https://researchrepository.wvu.edu/etd

Part of the Educational Psychology Commons

\section{Recommended Citation}

Hashemi, Mostafa, "An Examination of the Impacts of the WVU Research Apprenticeship Program (RAP)" (2020). Graduate Theses, Dissertations, and Problem Reports. 7565.

https://researchrepository.wvu.edu/etd/7565

This Thesis is protected by copyright and/or related rights. It has been brought to you by the The Research Repository @ WVU with permission from the rights-holder(s). You are free to use this Thesis in any way that is permitted by the copyright and related rights legislation that applies to your use. For other uses you must obtain permission from the rights-holder(s) directly, unless additional rights are indicated by a Creative Commons license in the record and/ or on the work itself. This Thesis has been accepted for inclusion in WVU Graduate Theses, Dissertations, and Problem Reports collection by an authorized administrator of The Research Repository @ WVU. For more information, please contact researchrepository@mail.wvu.edu. 
An Examination of the Impacts of the WVU Research Apprenticeship Program (RAP)

\section{Mostafa Hashemi}

Thesis submitted to the College of Education and Human Service

at West Virginia University

in partial fulfillment of the requirement for the degree of

Master of Arts in

Educational Psychology

\section{Reagan Curtis, Ph.D., Chair}

Paul R. Hernandez, Ph.D. Jake Follmer, Ph.D.

Department of Learning Sciences and Human Development

Morgantown, West Virginia

2020

Keywords: undergraduate research experiences, motivation, mentorship, TIMSI model Copyright 2020 Mostafa Hashemi 


\section{Abstract \\ An Examination of the Impacts of the WVU Research Apprenticeship Program (RAP) \\ Mostafa Hashemi}

Finding solutions to the problem of high attrition rates among students has been widely discussed by policymakers. Many intervention programs have been introduced to address this issue. The current study uses the tripartite integration model of social influence (TIMSI), (Kelman 1958, 1961; Estrada et al., 2011) to investigate and evaluate the effects of the research apprenticeship program (RAP), an intervention program aimed at supporting student performance and persistence through research and mentorship implemented at West Virginia University. The mediation analysis revealed research identity as a significant mediator in the relationship between RAP status and STEM persistence. Furthermore, RAP participants were able to create longer bonds with their faculties and integrate more into the academic community. 


\section{Acknowledgment}

First, I would like to thank Dr. Paul R. Hernandez for his support, words of encouragement, and teaching me everything I know about statistics. I first met him in 2017 , when I had an elective statistics course and at the time, I had no idea how much of an impact he would have on my personal and professional development. I am also very grateful to my committee members, Dr. Reagan Curtis and Dr. Jake Follmer for their invaluable feedback and all their help in the completion of this thesis. Lastly, I would like to thank my wife for always being there for me. 


\section{Table of Contents}

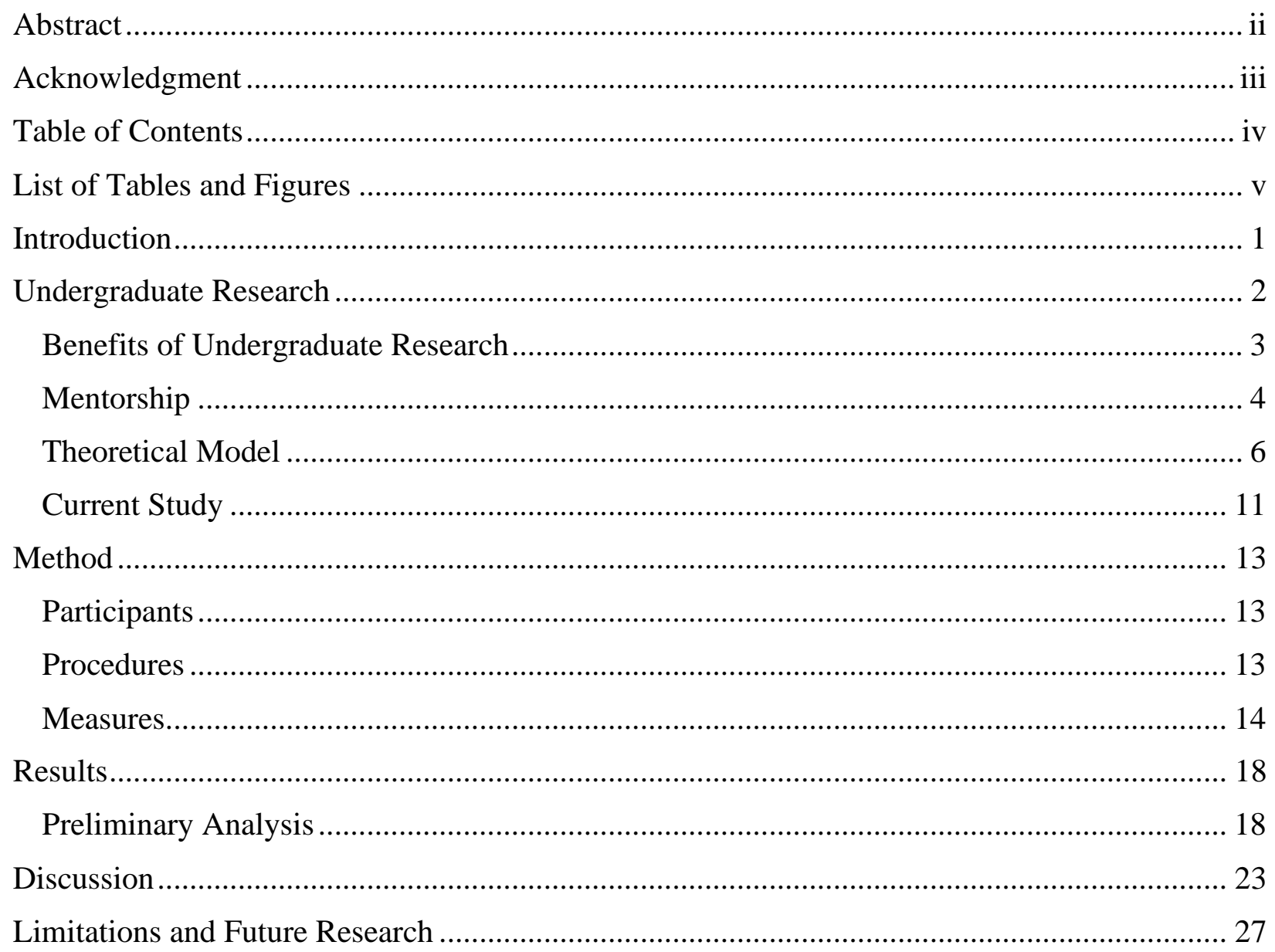




\section{List of Tables and Figures}

Table 1. Descriptive statistics of RAP and non-RAP students .....

Table 2. Descriptive statistics for mentoring, psychological mediators, and outcomes of interest as a function of group status

Table 3. Correlation matrix of the relationships among RAP status, mentoring, psychological mediators, and outcomes of interest.

Table 4. Summary of logistic regression predicting mentoring and academic persistence as a function of RAP status

Table 5. Summary of regression analyses predicting short-term mentorship-related outcomes from RAP, controlling for background characteristics

Table 6. Summary of general linear models predicting long-term mentorship-related outcomes from RAP, controlling for background characteristics

Table 7. Summary of general linear models predicting short-term persistence intentions-related outcomes from RAP status, controlling for background characteristics

Table 8 . Summary of general linear models predicting long-term persistence intentions-related and academic performance outcomes from RAP status, controlling for background characteristics.

Table 9. Summary of general linear models predicting short-term motivational variables from RAP status, controlling for background characteristics

Table 10. Summary of general linear models predicting long-term motivational variables from RAP status, controlling for background characteristics.

Table 11. Summary of regression-based mediation models assessing the total and indirect effect of RAP status on performance and persistence outcomes through motivational variables, controlling for background characteristic

Table 12. Summary of general linear models predicting long-term persistence intentions-related and academic performance outcomes from motivational variables, controlling for background characteristics

Table 13. Summary of general linear models and logistic regression predicting expected variables from RAP status, controlling for background characteristic

Figure 1. Tripartite Integration Model of Social Influence (TIMSI)

Figure 2. The mediation impact of TIMSI components on the relationship between RAP and its expected outcomes

Figure 3. Short-term significant relationships between RAP status, TIMSI components, and students' expected outcomes.

Figure 4. Long-term significant relationships between RAP status, TIMSI components, and students' expected outcomes. 


\section{An Examination of the Impacts of the WVU Research Apprenticeship Program (RAP) Introduction}

College students usually have many positive experiences during the first two years of school. However, some common problems such as cramming many courses into one semester, tuition costs, homesickness (especially for freshmen who are at least 3 hours away from home), and lack of adequate knowledge and skills to pass the required courses increase their stress level and their chances of dropping out during these two years (Berger, 2019; Boykin, 1994; GoCollege, 2019). Furthermore, many academic institutions fail to properly support high-risk students, which can lead to more students' attrition from college (Nagda et al., 1998). Although the college attrition rate in white American students is not as high as those among minority groups (Brower, 1992; Tinto, 1987), first- and second-year students with low GPAs usually are at greater risk for college attrition (Nagda et al., 1998). Solutions to this problem are now widely discussed. Christensen et al. (2014) contend that to drive innovation and broaden economic prosperity, the U.S. government must attract and retain more people in science, technology, engineering, and mathematics (STEM) careers. To attain this goal and generate the professionals who the country needs, some policymakers have suggested reducing attrition in college as a straightforward and low-cost approach (PCAST, 2012).

Although the phenomenon of students dropping out - caused by reasons such as personal dissatisfaction, financial impediments, and degraded career goals - is a major social problem (Ramist, 1981), the STEM students' attrition could have severe consequences regarding filling industry job vacancies (Belser et al. 2018). Chen and Soldner (2013) define the term "STEM attrition" as undergraduates moving away from STEM fields either by leaving education before

earning a degree or switching to a non-STEM major. Their statistical analysis report shows high 
STEM attrition rates and career path $(\sim 50 \%)$, and even higher attrition rates for non-STEM majors such as humanities and health science $(\sim 60 \%)$. Retaining more undergraduates is a severe challenge for academic programs.

\section{Undergraduate Research}

Finding solutions to the problem of high attrition rates among students will help students pursue higher academic levels, get better post-baccalaureate jobs, and contribute more to society (Millea et al., 2018). Undergraduate research is a "high impact practice" to engage students and is increasingly identified as a potential intervention to promote college and STEM field retention (Kuh, 2008). Research indicates that a range of different programs and opportunities have been tested to increase students' performance (e.g., GPA) and intentions to persist in college in addition to a post-baccalaureate research career (Ritchey et al., 2015; Russell et al., 2007). Undergraduate research experiences include a variety of different goals ranging from articulating clear research questions and formulating hypotheses to knowing the relevant literature and demonstrating appropriate research method (Linn et al., 2015; Lopatto, 2003). In addition, research experiences are typically conducted in the forms of co-curricular undergraduate research experiences (UREs, e.g., summer UREs) or course-based undergraduate research experiences (CUREs). UREs are apprenticeship-style research experiences which provide oneto-one mentoring opportunity and only a few students can be accommodated in the settings, typically a few select students with high quality and eagerness (Hernandez et al., 2018; OlivaresDonoso \& González, 2019; Reboredo et al., 2014; Sadler et al., 2010). By contrast, CUREs are not typically competitive; provide a systematic curriculum including classes, credits, grades, and assignments usually supervised by a course instructor (Linn et al., 2015; Rodenbusch et al., 2016). In addition, undergraduate research can be conducted through either formal or informal 
approaches (Maltese et al., 2017; Nagda et al., 1998). Formal approaches, unlike informal ones, are structured programs with designated times, formal applications, and financial supports (University of Chicago, n.d.).

\section{Benefits of Undergraduate Research}

A growing body of research indicates that undergraduate research supports current and future STEM career engagement and persistence, particularly. In their study, Hernandez et al. (2018) showed the significant impact of informal undergraduate research experiences on students' academic performance and persistence in science of racial/ethnic minority students in STEM fields. Using a large-scale research design, they concluded that, compared to students with no research experiences, those students who participated in URE(s) were more inclined to "graduate with a science-related bachelor's degree, to be accepted into a science-related graduate training program, and to be training for or working in the scientific workforce 6 years after graduation" (p. 204).

In addition, the Undergraduate Research Opportunity Program (UROP) is one of the formal programs that successfully provides support and training for a large sample (more than 600 participants) of underrepresented minority undergraduate students (Nagda et al., 1998). Through the UROP program, Nagda and colleagues aimed to develop an intellectual relationship between undergraduate students - mostly first year and sophomore underrepresented minority students - and their faculty research advisors through research partnership which resulted in significantly higher retention among UROP participants. Looking at the other end of students' timeline (i.e., the graduation from college), Hathaway et al. (2002) examined the UROP and found the significant impact of the program on students' likelihood of pursuing graduate 
education and involving in research activities. Ultimately, Linn et al. (2015) argued that although undergraduate research comes with considerable costs (i.e. extensive time, money, and effort), the benefits outweigh the costs because it engages students in authentic experiments, which enculturate students into scientific investigation and empower them to take responsibility for conducting independent research.

In addition to retention-related benefits, UREs and CUREs help students gain knowledge and self-confidence through independent research, help them make professional relationships with their instructors/mentors, and help them learn how to explore new areas inside their fields (Bangera \& Brownell, 2014). Being self-reliant and finding one's own path without imitating professors leads undergraduate students to create "real science" as an overarching and recurring theme (Laursen et al., 2010). According to Thiry et al. (2011), research experiences, in general, offer students "the opportunity to take ownership of a real-world project, clarify future career goals, and begin to develop an identity as a professional" (p. 383). Despite all of the benefits associated with undergraduate research experiences, there are noticeable challenges regarding new students interested in conducting research. Balster and colleagues (2010) identified barriers such as: finding an appropriate mentor, evolving from the regular classrooms into a learning research environment, and intending to be a part of the research community - and asserted the importance of overcoming these challenges on acquiring a scientific research workforce. In their efforts to train such professional researchers Balster and colleagues developed a course called "Entering Research" to help novice undergraduate researchers overcome these challenges.

\section{Mentorship}

Mentoring is considered as necessary as having a high-quality research experience. In other words, given the reported personal, professional, and intellectual achievements from 
experiencing undergraduate research experiences (Hunter et al., 2007; Seymour et al., 2004), those achievements would not be possible without faculty mentors' collaborations and supports (Hunter et al., 2007). Researchers specifically stress the importance of having mentors to become masterful in sports (Harrison et al., 2006), overcome severe physical challenges (Powers et al., 1995), develop careers (Kram \& Isabella, 1985), make academic achievements (Thompson \& Kelly-Vance, 2001), and even increase the retention rates (Salinitri, 2005). Although there is no single definition of the mentor-protégé relationship, it is frequently defined as "a learning and development partnership between a professional with in-depth experience and knowledge in a specific area and a protégé seeking learning and coaching in the same area" (Farren, 2006, p.1).

Eby et al. (2013) discuss different characteristics of mentoring and conclude that mentoring is not the same as other types of close relationships (e.g., friendships). In their metaanalyses of mentor-protégé studies, Eby and colleagues identify protégé perceptions of instrumental support, psychological support, and relationship quality as three major elements which help scholars understand how and why mentoring has a positive impact on protégé. First, as a type of career-related advice, instrumental support helps students have more research experiences and support them through professional development (Flaxman et al., 1988; Nakkula \& Harris, 2005). Such practical support can include "the specific mentor behaviors of providing task-related assistance, sponsorship, exposure and visibility, and coaching” (Eby et al., 2013, p. 443). The second factor is perceived as psychosocial support. The protégé's perception of competence and worthiness can be enhanced through this factor which involves facilitating the emotional and personal development of students (Nakkula \& Harris, 2013). Mentor psychosociology usually consists of some special behaviors including "offering counseling, unconditional acceptance, encouragement, and role modeling.” (Eby et al., 2013, p. 443). 
Identifying relationship quality as the mechanism by which mentoring affects protégé, Nakkula, and Harris (2005) emphasize the importance of relationship closeness. Relationship quality describes how the mentee feels and appreciates her/his relationship with the mentor and mentorship all together and determines to what extent the mentee is satisfied with the mentor and the mentoring process (Eby et al., 2013).

\section{Theoretical Model}

Inspecting students' attrition at each step of their academic journey (i.e., academic pipeline) has encouraged policymakers and researchers to better understand which type of students are more likely to drop out from school (Delen et al., 2020), what are their underlined reasons (Braxton, 2019; Estrada et al., 2011; Rosenzweig et al., 2020), and how stakeholders can support vulnerable students on their academic journey (DePass \& Chubin, 2009; NAS, 2017; Schultz et al., 2011). To get to these goals, many theoretical social models (e.g., Bean, 1980; Spady, 1971; Tinto, 1987) have been developed, modified and utilized to create different undergraduate research programs and explain for whom, under what conditions, and how those programs work (Aljohani, 2016; Burke, 2019).

In this study, I adopted a validated social psychological model known as the tripartite integration model of social influence (TIMSI), (Kelman 1958, 1961; Estrada et al., 2011) to investigate and explain the relationship between research and its expected outcomes (Figure 1). Prior research with TIMSI has shown students' integration into the scientific community. The model consists of three processes of social influence (i.e., research self-efficacy, research identity, and community objective values) (Estrada et al., 2011). Each of these processes enhances students' motivation and therefore will lead to higher performance and persistence differently. The model emphasizes on the role of social influence - changes in one's emotions, 
beliefs or behaviors as a result of being affected by the influencer or society (Mcallister, Iii, \& Ferris, 2018) - and predicts that being socially influenced by the academic society would increase people's self-efficacy, self-identity as a scientist, and internalization of the academic community values. In the expansion of his model, Kelman (2006) focused on different contexts of influence situations and categorized them as socialization (i.e., the process of accepting the norms and values of the society) and resocialization (i.e., the process of transitioning from old norms and values to the new ones). Considering students integration into the scientific community as a type of resocialization, the model proposes a theoretical foundation to understand how different student support programs (e.g. Bridges, MARC, RISE, etc.: NAS, 2005) encourage students to perform better and persist more in the scientific community. Furthermore, in their study of integrating underrepresented minorities into STEM majors, Estrada et al. (2018) found a positive relationship between integration into STEM and three components of TIMSI model (i.e., science efficacy, identity, and values) as a result of participation in undergraduate intervention programs. In fact, implementing reliable intervention programs that offer opportunity, support, and training experiences is one of the major goals of many higher education institutions to help increase retention and graduation rates of their students (Chance, 2013).

Research Self-efficacy. The first component of the TIMSI model, research self-efficacy, is an important psychological predictor for exerting efforts to continue in academic line despite its difficulties and unpredictability. Albert Bandura (1997) describes self-efficacy as "the belief in one's capabilities to organize and execute courses of action required to produce given attainments" (p. 3). In other words, self-efficacy means we can reach our goals by having confidence in our ability to do so. Different studies have found a positive correlation between 
self-efficacy and persisting in reaching desired goals. For example, Stajkovic and Luthans (1998) found that people with high self-efficacy are willing to endeavor more and more until they achieve their goals while people with low self-efficacy are willing to give up in the early stages without implementing most of their abilities. Estrada et al. (2011) considered scientific selfefficacy an indicator of Kelman's compliance (i.e., accepting influence form others in order to get rewards or avoid punishments) happening as a result of successfully following scientific communities' rules and principles. Büyüköztürk (2011) defined research self-efficacy as “one’s confidence in his ability to successfully complete tasks such as literature reviews and data analyses" (p. 23), arguing that students with higher research self-efficacy usually have greater tendency to select effortful research related tasks.

Research Identity. While self-efficacy occurs through transformation in behavior but not necessarily in attitude, identification is the result of transformation in both behavior and attitude (Kelman, 1958); therefore, indicates a stronger integration into the scientific community. According to Kelman, identification arises as a result of being affected by others which leads to “establish or maintain a satisfying self-defining relationship to the others.” (Kelman, 2006, p. 3). Estrada et al. (2011) defined scientific identification as accepting science as part of individual identity. This acceptance connects individual with the members of the science community and creates a sense of community belonging. In their study of explaining undergraduate minority students integration into the scientific community, they considered science identity as accepting a new role as a scientist and argued that " the more a person identifies as a scientist, $[\ldots]$ the more likely the person would be to behave in a manner consistent with the expectations of that role and to pursue a scientific career" (Estrada et al., 2011, p. 209). 
During their educational experiences, students are usually exposed, mostly indirectly, to multiple identities and invisible barriers. Therefore, the process of identification and following the academic norms could be complex (Hamilton, 2004), and stressful (Azmitia et al., 2008), inasmuch as many students cannot follow those norms properly; hence, cannot fit in the scientific community as expected (Estrada et al., 2011; Syed et al., 2019). As mentioned before, identification indicates a stronger and deeper integration than one required for self-efficacy. Therefore, if the integration into the scientific community does not reach the degree that one can imagine herself as a scientist, even skilled students with high self-efficacy might not be able to significantly improve their academic performance and persistence (Estrada et al., 2011). Furthermore, a number of studies have demonstrated the superiority of scientific identity over racial or ethnic identity on predicting academic performance and persistence in college (ByarsWinston \& Rogers, 2019; Osborne \& Walker, 2006; White et al., 2019). Consistent with many studies (Hernandez et al., 2018; Martin-hansen, 2018; Stets et al., 2017), this study anticipates that having a strong research identity (i.e., the way a person sees herself in terms of being a researcher) would be a good predictor of academic performance, persistence, and intention to pursue a research career.

Community objective values. The scientific community, similar to any other community, has its principles and values which are needed to be acknowledged and accepted by all community members. Internalization, as the process of accepting or receiving those principles and values, occurs when a member accepts influence from the community "to maintain the congruency of actions and beliefs with his or her value system" (Kelman, 2006, p. 4). In this process, a set of norms is usually established by influencers and is accepted by individuals because those norms are congruent with the individual's value system. According to Kelman, the 
content of new behavior is considered as the "reward" of such internalization. Estrada et al. (2011) and colleges contend that the process of internalization occurs when people's primary motivation is extracted from their authentic valuing of the objectives of the scientific community. In other words, people change their behavior based on those values because they are intrinsically satisfying to them and people are happy with those values being part of them. In their study of motivational patterns among minority students, Taylor and Graham (2007) measured values by asking participants to nominate "peers whom they admired, respected, and wanted to be like" (p. 52). Next, by assessing the achievement level of the nominated individuals (i.e., low, average, or high), values were calculated. As Kelman (2006) contends, each component of the TIMSI model has its source of power (i.e., self-efficacy: reward and punishment; identification: attractiveness; and internalization: credibility) which motivates individuals and stirs them to action uniquely. Furthermore, both self-efficacy and identification are the results of external behaviors (i.e., specific rules of the community and specific expectations of accepting a role within the community, respectively); hence, they have a temporary nature. Namely, as soon as the reward system or the expectations related to a specific role ceases, people stop getting influenced by the community. On the other hand, resulting from individual's inner value system, internalization is not dependent upon external behaviors; thus, this process of social influence can create more effective and last longing changes in individual's behavior than other processes can (Chance, 2013; Kelman, 1958, 2006). Empirical evidence highlights the positive link between endorsing the community objective values and deeper integration into the scientific community which results in more academic persistence (Chance, 2013; Estrada et al., 2011).

In summary, because many undergraduate research programs show significant effects on academic performance and persistence of students in a variety of situations (Hathaway et al., 
2002; Hernandez et al., 2018; Stajkovic \& Luthans, 1998), a lot of undergraduate research programs are being provided by different institutions across the country. In other words, it is evident that these programs significantly impact the retention and graduation rates of an increasing number of students. However, the number of comprehensive analyses that describe how these programs work is small. Therefore, the goal of this study is to describe the mechanism of such programs and analyze the process by proposing a model of social influence (i.e., TIMSI model). The model consists of three processes of attitude changes (i.e., research self-efficacy, research identification, and community objective values) which help determine the effects of the model. Each process of social influence is unique in its source of power and the way it motivates students to perform better and persist more in college.

\section{Current Study}

The current study uses the TIMSI theoretical model to investigate and evaluate the effects of the research apprenticeship program (RAP), an intervention program aimed at supporting student performance and persistence through research and mentorship implemented at West Virginia University.

Through March, April, and May, information about RAP positions is posted in MountaineerTRAK, the WVU's site for searching about career fairs and events. RAP program is usually introduced to new students on the first day of school at university orientations. The Undergraduate Research Symposiums in spring is another opportunity to encourage prospective students to join WVU and RAP. At the symposium, graduated RAP students present their research. Based on students' interest and resume, they would be asked to work with designated faculties and sign a mentor-mentee contract. 
The program provides a research opportunity for federal work-study (FWS) students, students with financial need who already applied for the free application for federal student aid (FAFSA); and is considered 1 credit for each semester. Participants in RAP may also benefit by having a faculty member as their research mentor. They then spend 7-10 hours a week working with their respective mentors in support of ongoing research initiatives, becoming familiar with the practical applications of their studies, and developing their research interests. Research apprentices are required to participate in a weekly class session, including activities such as reading required literatures, getting collaborative institutional training initiative (CITI) certificate, finding research articles, learning to get institutional review board (IRB) approval, managing their time, learning to work with their mentors, inviting experienced undergraduates to class, writing abstracts, and making presentation (RAP syllabus). Furthermore, every other week they need to submit a report regarding their progress and experience in the program. During the summer until the drop-out deadline for WVU students, the program used all recruitment instruments and accepted 52, 12, and 95 new FWS students respectively for cohort 1 (fall 2017 - spring 2018), cohort 2 (spring 2018 - fall 2018), and cohort 3 (fall 2018 - spring 2019). Cohort 2 was comparatively small because it was an off-sequence cohort.

This study intends to compare students who participate in the RAP (i.e., the treatment group) with students who do not participate in any undergraduate research program (i.e., the control group). Finding statistically significant higher outcomes (i.e., higher academic performance, academic persistence, and intention to pursue in research career) in the treatment group implies the significant effects of the RAP as an intervention program. To create the bestmatched control group, propensity scores have been utilized to reduce or eliminate selection bias. 
Utilizing the TIMSI model, this study aims to analyze the RAP process as a type of undergraduate research program to understand the mechanism of students' attrition rates and describe how the RAP program accomplishes its missions. The following research questions are aimed at understanding the effects of RAP.

1. To what degree does RAP impact students' mentorship support, quality of that support, and mentor network diversity?

2. To what degree does RAP impact academic performance, persistence, and intention to pursue a research career in the short-term and long-term?

3. To what degree is any potential effects of RAP (consisting of course-works and mentorship supports) on students' academic performance, persistence and intention to pursue a research career mediated through the social influence processes identified in the TIMSI model (efficacy, identity, and values)?

\section{Method}

\section{Participants}

From fall 2017 until fall 2018, in total, 293 (STEM and non-STEM) students participated in this study, with 138 students ( 45\%) in the RAP group and 155 students $(\sim 55 \%)$ in a matched comparison group. Table 1 shows descriptive statistics of RAP and control groups based on the data and WVU administrative records. The sample mostly consists of White students (more than $80 \%$ ) in their first two years of college, with more females than males.

\section{Procedures}

The data for this study were collected from a longitudinal study of West Virginia University students with limited research experiences surveyed in fall 2017, spring 2018, and fall 
2018. It is worth to note that the RAP program was designed explicitly for students with limited research experiences. Data collection occurred through an online survey at the end of each semester. Other information such as GPA, majors, school grades, SAT, and persistence at WVU were obtained from WVU administrative records. An online survey is launched at the end of each semester through Qualtircs. For the fall cohorts (i.e., cohorts 1 and 3) the survey is launched in November and December and for the spring cohorts (i.e., cohorts 2) the survey is launched in April and May. All procedures are reviewed and monitored by the local institutional review board (IRB) to protect the right and welfare of the participants.

Propensity score matching approach. Administrative records were gathered to identify and match RAP students with FWS eligible students that did not participate in RAP. RAP students and control group students for the fall cohorts were matched in October and November. Propensity score matching (PSM) was conducted for cohorts, federal work study status, offered money, major, overall GPA, rank (i.e., freshman, sophomore, ..), gender, race, first generation status, citizenship status, permanent state, legacy, high school GPA, first time status, and SAT factors, and post-matching. The PSM results showed major, rank, race, cohorts, and high school GPA as unbalanced variables (i.e., there were small-to-moderate differences across RAP and comparison groups after matching). All unbalanced variables were used as controls/covariates in the analyses. Since there are not many new students joining the program in the spring semester, the match process is not applied for the spring cohort.

\section{Measures}

\section{TIMSI-related measures}

Research self-efficacy. For assessing the participants ability to function as scientist in a variety of tasks, I used a six-item scales, modified from Chemers et al. (2010) original 14-item 
scientific self-efficacy scale, and asked students to rate their confidence to complete items such as "use technical skills (use of tools, instruments, and/or techniques)," and "generate a research question to answer," from 1(not at all confident) to 5 (absolutely confident). The self-efficacy scale was assessed by calculating the average score of six items. A higher number indicates a higher level of self-efficacy. Cronbach's alpha of .96 has been reported for scientific selfefficacy (Chemers et al., 2011). High internal consistency of self-efficacy scales (Cronbach's alpha $=91)$ was also reported by Estrada et al. $(2011)$.

Research identity. A modified version of the Scientific Identity Scale (Chemers et al., 2011) was used to assess the participants feeling of belonging. This version included four items. Participants were asked to assess on a scale of 1 (strongly disagree) to 5 (strongly agree) to what extent they agree with items such as "I have come to think of myself as a scholarly researcher in my area of study." The scale was assessed by calculating the average score of four measurement items. A higher number indicates a higher level of research identity. Cronbach's alpha of .89 has been reported for research identity (Chemers et al., 2010).

Community objectives values. To assess the participants' internalization, four indicators created by Estrada et al. (2011) were used. Participants were asked to rate how much the person in the description is like them in items such as "A person who thinks discussing new theories and ideas between researchers is important." Response options included: not like me at all, not like me, a little like me, somewhat like me, like me, and very much like me. The community objectives value scale was assessed by calculating the average score of four measurement items. A higher number indicates a higher level of community objectives value. Estrada et al. (2011) have found high internal consistency $(\alpha=.85)$ for value orientation scale.

\section{Measures of faculty-mentored research experience}


Have a primary faculty mentor. Defining a mentor as "someone who provides guidance, assistance, and encouragement on professional and academic issues", students were requested to respond to the following binary question: "Is there a faculty member that you would consider a mentor?" (Hernandez et al., 2017). Only students with a "Yes" response to this question were eligible to answer the subsequent mentorship quality questions.

Mentor psychosocial and instrumental support. A four-item psychosocial support scale used in prior research (Tenenbaum, Crosby, \& Gliner, 2001), adapted form 18 items of the mentoring scales which Dreher and Ash (1990) developed from the global measure of mentoring practice (GMMP), asked participants to assess the amount of their primary faculty psychological support by answering questions such as "To what extent has your mentor discussed your questions or concerns regarding feelings of competence, commitment to advancement, or relationships with peers?" Each statement was assessed on a scale of 1 (strongly disagree) to 7 (strongly agree). The psychological support scale was assessed by calculating the average score of four measurement items. A higher number indicates a higher level of psychological support.

A six-item instrumental support scale used in prior research (Tenenbaum et al., 2001), asked participants to assess the amount of their primary faculty instrumental support by answering questions such as "To what extent has your mentor helped you finish assignments/tasks or meet deadlines that otherwise would have been difficult to complete?" Each statement was assessed on a scale of 1 (strongly disagree) to 7 (strongly agree). The instrumental support scale was assessed by calculating the average score of six items. A higher number indicates a higher level of instrumental support. The psychosocial help had an $\alpha$ of .93, and instrumental support had an $\alpha$ of .83 (Tenenbaum et al., 2001). 
Mentoring satisfaction. A three-item mentoring satisfaction scale used in prior research (Ensher \& Murphy, 1997), asked participants to assess how much they are satisfied with their primary faculty mentors on a scale from 1 (Strongly disagree) to 5 (Strongly agree). The participants were asked to rate items such as "I effectively used my mentor to help me develop." The mentoring satisfaction scale was assessed by calculating the average score of all three items. A higher number indicates a higher level of satisfaction with their primary faculty mentors. The inter-reliability between items is defined as $\alpha=.90$ (Ensher \& Murphy, 1997).

\section{Other measures of mentoring}

Mentor network diversity. In addition to the faculty mentors, sometimes other people such as teachers, program staff, graduate students, etc. mentor the students. A seven-item mentor network diversity scale asks students whether they receive mentoring from "a primary faculty mentor," "Faculty mentors other than their primary faculty mentors", "Teachers", "Program staff members", "Postdoctoral fellows", "Guidance Counselors", and "Peers". The mentor network diversity index score was calculated as the sum of the seven-items, with scores ranging from 0-7.

\section{Outcome measures}

Intentions to pursue a scientific, humanities, or medical research career. To assess the participants' intentions to pursue a research career in STEM-related degrees, three indicators created by Woodcock et al. (2015) were used. Participants were asked to rate the likelihood of their intention to remain and continue in a research career on items such as "What is the likelihood of you obtaining a science-related undergraduate degree?" from 0 (Definitely will not) to 10 (Definitely will). The intention to pursue a scientific research career scale was assessed by calculating the average score of the three items. A higher number indicates a higher level of 
intention to pursue a scientific research career. The internal consistency reliability between items is defined as alpha $=.81$ (Woodcock et al., 2015).

To assess the participants' intentions to pursue a research career in humanities-related degrees, three indicators created by Woodcock et al. (2015) were used. Participants were asked to rate the likelihood of their intention to remain and continue in a research career on items such as "What is the likelihood of you obtaining arts or humanities-related undergraduate degree?" from 0 (Definitely will not) to 10 (Definitely will). The scale was assessed by calculating the average score of three items. A higher number indicates a higher level of intention to pursue a humanity research career.

To assess the participants' intentions to pursue a research career in medical-related degrees, two indicators created by Woodcock et al. (2015) were used. Participants were asked to rate the likelihood of their intention to remain and continue in a research career on items such as “To what extent do you plan to pursue a medical-related graduate degree?" from 0 (Definitely will not) to 10 (Definitely will). The scale was assessed by calculating the average score of two items. A higher number indicates a higher level of intention to pursue a medical research career.

Cumulative GPA (institutional data). Cumulative college GPA was obtained from the WVU administrative office and was measured on a scale from 0 to 4 .

Persistence at WVU (institutional data). Students were checked after 1 year to know if they have continued at WVU or not.

\section{Results}

\section{Preliminary Analysis}

Prior to analyzing the data with the planned regression analyses, the assumption that data were missing completely at random was examined using Little's MCAR test (Little, 1988). The 
test results did not reject the null hypothesis that the data were missing completely at random, $\chi 2(61)=67.88, p=0.25$; therefore, analyses proceeded without concern for missing data bias. Next, outlier analyses were conducted by checking standardized deleted residuals, Cook's D values, and leverage values and the results indicated that no outlier cases were identified in the data set (Judd et al., 2009). Finally, residual diagnostics, the assumptions of linearity, homoscedasticity/homogeneity of variances, normality within groups, and homogeneity of regression slopes were examined. Residual diagnostics showed that the assumptions of regression analyses were tenable.

Distributional assumptions and descriptive statistics as a function of group status were examined, as well as short- and long-term associations among the variables. The results indicated that the distribution of all variables of interest did not depart from normality, Table 2.

Furthermore, inspecting the pattern of bivariate association among the variables of interest indicated statistically significant positive correlations between RAP status and all psychological mediator variables, as well as short- and long-term intention to pursue a scientific research career, Table 3. Besides, results revealed positive associations between the mediators and all persistence intention-related variables.

Direct effects of RAP status on mentorship. The first research question examines the impact of RAP on having a faculty mentor, the quality of faculty mentorship support received, and the size of the mentorship network. First, logistic regression was conducted to test the impact of RAP status on the likelihood of having a faculty mentor. Second, since not all students have faculty mentors, a subgroup of students who had faculty mentors was created. Then three general linear model regressions were conducted to examine the impact of RAP on students' instrumental support, psychological support, and mentor satisfaction. Third, a regular regression analysis 
compared mentor network diversity, as an intermediate outcome, between RAP and control group. Based on the previous literature and the RAP program goals, I hypothesized that being part of RAP will significantly increase the impacts of mentorship support, the quality of mentor on students, and their mentor network diversity.

In the equation below, the dependent variable is mentorship support (i.e., instrumental support, psychological support, and mentor satisfaction). Model A investigates the impact of the program on both RAP and control groups, whereas model C investigates the impact of the program on the control group. The difference between models A and C will test the impact of RAP on mentorship support between the experimental (i.e., RAP) and the control group.

Model A: Y $=\beta 0+\beta 1($ Major $)+\beta 2($ Rank $)+\beta 3($ Race $)+\beta 4($ Cohort $)+\beta 5($ HS_GPA $)+\beta 6($ RAP $)$ + error

Model C: $Y=\beta 0+\beta 1($ Major $)+\beta 2($ Rank $)+\beta 3($ Race $)+\beta 4($ Cohort $)+\beta 5($ HS_GPA $)+$ error

For computing the minimum detectable effect size, G*Power (Faul et al., 2007) was used for this question as well. Using .8 power level, alpha level 5\%, one tested predictor, and three total predictors, for the sample of 300 participants the $\mathrm{G}^{*}$ Power results indicated $R 2=.03$ as the minimum detectable effect size.

The results indicated significant impact of RAP status on students' having a faculty mentor (Table 4). More specifically, the odds of having a faculty mentor were 13-times higher in the short-term and 15-times higher in the long-term for the RAP group compared to the control group. Furthermore, the results indicated no effects of RAP status on faculty mentor satisfaction, faculty mentor psychological support, faculty mentor instrumental support, or mentor network diversity in the short- or long-term, (Tables $5 \& 6$ ). 


\section{Direct effects of RAP status on academic performance and persistence in college. Three} general linear model regressions were used to evaluate the impact of RAP on short- and longterm academic performance, academic persistence, and intention to pursue a research career. First, for examining the impact of the program on academic performance and intention to pursue a research career, regular regression was utilized. Second, considering persistence at WVU as a categorical variable, logistic regression was used to address the impact of RAP on how far the students continued their academic journey at WVU. In the equation below, the dependent variables are expected RAP outcomes (i.e., academic performance, academic persistence, and intention to pursue a research career). Model A investigates the impact of the program on both RAP and control groups, whereas model C investigates the impact of the program on the control group. The difference between models A and C will test whether the RAP program improves outcome prediction over the control group.

Model A: $\mathrm{Y}=\beta 0+\beta 1($ Major $)+\beta 2($ Rank $)+\beta 3($ Race $)+\beta 4($ Cohort $)+\beta 5($ HS_GPA $)+\beta 6($ RAP $)$ + error

Model $C: Y=\beta 0+\beta 1($ Major $)+\beta 2($ Rank $)+\beta 3($ Race $)+\beta 4($ Cohort $)+\beta 5($ HS_GPA $)+$ error

Based on the previous literature (Estrada, 2014; and Estrada et al., 2018), I hypothesized that being part of the RAP would positively improve students' academic performance, academic persistence, and intention to pursue a scientific, medicine, and humanity research career.

For computing the minimum detectable effect size, G*Power (Faul et al., 2007) was used for this question as well. Using .8 power level, alpha level 5\%, one tested predictor, and three total predictors, for the sample of 300 participants the $\mathrm{G}^{*}$ Power results indicated $\mathrm{R} 2=.03$ as the minimum detectable effect size. 
The results indicated a significant effect of RAP status on short- and long-term STEM career persistence (Tables $7 \&$ 8), as well as cumulative GPA (Table 8). More specifically, RAP reported stronger STEM career persistence intentions and had higher GPAs than their non-RAP. However, logistic regression analysis indicated that RAP status did not impact academic persistence, (Table 4).

Indirect effects of RAP status on its expected outcomes through TIMSI components. As a final step, I tested the degree to which psychological factors mediated the relationship between RAP status and performance and persistence-related outcomes using a bootstrapping approach to construct confidence intervals around the indirect effect of the RAP on the outcomes of interest (Shrout \& Bolger, 2002). Using Med-power - and identifying a-path = .18, b-path = .19, c'-path $=.10$ with $5 \%$ alpha level - the power level of indirect effect was calculated as .80 with ab (indirect) $=.03$ for 300 participants as the given sample size.

As a preliminary analysis, I examined the degree to which RAP status predicted shortand long-term motivation levels (i.e., research self-efficacy, research identity, and community objective values) using a series of general linear models. The results revealed significant effects of RAP status on short- and long-term motivation variables, such that RAP students exhibited higher motivation (Tables $9 \& 10$ ). Next, I tested the indirect effects of RAP status on academic performance through research self-efficacy, research identity, and community objective value levels using a regression-based mediation analysis (Hays 2013; Process Macro Model 4) with 10,000 bootstrapped samples, controlling for background variables (Figure 2). The results revealed a statistically significant indirect effect of RAP on cumulative GPA through none of the motivation elements (Table 11). Next, six identical regression-based mediation analyses were 
performed to test the indirect effect of RAP on short- and long-term intention to pursue a scientific, medicine, and humanity research career. Research identity significantly mediated the impact of RAP on short-term intention to pursue a humanity career, as well as long-term intention to pursue a scientific research career variables (Table 11). Furthermore, community objective value mediated the impact of RAP on short-term intention to pursue a scientific research career. Figures 3 and 4 summarize all short and long-term significant relationships between RAP status, TIMSI components, and students' expected outcomes.

\section{Discussion}

Many studies have demonstrated the benefits of participating in undergraduate research experiences in a variety of situations (Hathaway et al., 2002; Hernandez et al., 2018; Stajkovic \& Luthans, 1998). However, the number of comprehensive analyses that describe why these programs work is relatively small. Addressing this gap, this study has attempted to describe why the RAP intervention program, conducted at WVU, encourages students to increase performance, persistence, and intention to pursue a research career. Namely, considering students' integration into their disciplinary community to be a good fit for the classic social influence pattern - with the scientific community as the influencing agent, and students as the target of influence(Kelman, 1956, 2006, Estrda et al. 2011), this study aims to explain how students integrate into and socialize with their academic community. To get to this goal, this study utilized a modified version of the TIMSI model, a social influence model developed by Kelman $(1958,2006)$ and extended by Estrada et al. (2011). I tested how the TIMSI is explaining the relationship between RAP status and its expected outcomes. In general, based on the previous literature, I expected stronger indicators of RAP participants' integration into the scientific community (i.e., research 
self-efficacy, research identity, and community objective values) compared to those for non-RAP students (Estrada et al., 2011, 2018).

\section{The effects of RAP status on mentorship support and quality of that support in addition to}

having a faculty mentor and mentor network diversity. Participants in RAP may benefit by

having a faculty member as their formal mentor. Examining the impact of RAP status on having a formal faculty mentor, the results indicate a significantly higher likelihood of having a faculty mentor between RAP and control groups. However, the program has not made any significant difference in terms of receiving informal mentoring supports from (i.e., the support from mentors other than their assigned faculty mentors). Undergraduate students usually spend more time with their potential informal mentors (e.g., graduate students, program staff members, and peers) than with assigned faculty mentors (Thiry et al., 2011). While acknowledging the commonality of formal mentoring, many studies (such as Insala 2019; and Holt et al., 2016) have paid close attention to the informal mentoring as a practical approach to enhance the effects of the formal one. Although the results indicate receiving the same level of mentor network diversity by either RAP or non-RP students, the RAP students' higher likelihood of having faculty mentors (i.e., formal mentoring) would improve their academic outcomes remarkably. Limiting the effects of informal mentoring - mentoring by mentors other than students' assigned faculty mentors - to solving technical issues, many studies consider experiencing formal faculty mentoring as the best way to develop complex scientific skills and professional scientific identity (Feldman et al., 2013; Strawn \& Livelybrooks, 2012). Therefore, combining informal and formal mentoring, RAP participants would have a better chance to stay on their academic pipeline.

This study also examined protégé perceptions of instrumental support, psychological support, and satisfaction to measure the impact of RAP status on mentorship quality. The 
analysis found no significant difference in mentorship experience - in terms of instrumental support, psychological support, and mentor satisfaction - between RAP and non-RAP students. In other words, the faculty members of WVU provide the same level of professional and emotional support in addition to the satisfaction of the mentoring process inside and outside the RAP program.

\section{Direct Effects of RAP status on academic performance and persistence in college in addition}

to intention to pursue a research career. Regarding the number of semesters and weekly research hours (i.e., the duration and intensity of research experience, respectively) as determinants of a successful program, Hernandez and Woodcock, et al. (2018) found completing at least two semesters of 10 hours weekly research as the most beneficial undergraduate research experience. Therefore, the RAP participants - spending 7-10 hours a week for two semesters of $\mathrm{RAP}$ - are expected to show higher academic outcomes compared with matched undergraduate students not in the program. The results indicated a significant effect of RAP status on shortand long-term STEM career persistence, as well as cumulative GPA. However, the findings did not reflect the impact of the program on academic persistence. These results, in general, are consistent with the previous studies on college retention and graduation rates (Hathaway et al., 2002; Hernandez, Woodcock, et al., 2018; Stajkovic \& Luthans, 1998). Although the percentage of persistence among RAP participants (86\%) was higher than that in matched no-research controls $(81 \%)$, the analysis did not show any significant difference between the two groups. While it is difficult to interpret a null effect, the lack of difference between the groups may reflect other factors are at play in college retention, such as family loneliness and lack of money (Berger, 2019; Boykin, 1994; GoCollege, 2019). 
Indirect effects of RAP status on its expected outcomes through TIMSI components. The overarching purpose of this study was to understand why the RAP contributes towards students' performance and persistence, via three TIMSI processes of social influences. Consistent with the previous literature (Litzer et al. 2014; Barlow \& Villarejo, 2004; Estrada et al., 2011, 2018), the preliminary analysis showed significant effects of RAP status on TIMSI components (i.e., research self-efficacy, research identity, and community objective values) in addition to the intention to pursue a scientific research career and GPA (see Figures $3 \& 4$ ). However, participating in RAP did not contribute to students' intention to pursue a humanity or medicine research career. Furthermore, in the long-term, TIMSI components only contribute to the intention to pursue a scientific research career and cumulative GPA. Moreover, none of the TIMSI integration factors did explain the positive effects of RAP status on the cumulative GPA. Overall, the hypothesis regarding the indirect effects of RAP, through TIMSI components, on the intention to pursue a scientific, medicine, and humanity research career in addition to GPA was partially supported, such that only research identity significantly explained the indirect effect of participating in the RAP on the intention to pursue a scientific research career in the long-term (see Tables $12 \&$ 13). Estrada et al. (2011) contended that identification indicates a stronger and deeper integration than one required for self-efficacy. Therefore, if the integration into the scientific community does not reach the degree that one can imagine herself as a scientist, even skilled students with high self-efficacy might not be able to significantly improve their academic performance and persistence. As Kelman (2006) contended, each component of the TIMSI model has its source of power (i.e., self-efficacy: reward and punishment; identification: attractiveness; and internalization: credibility) which motivates individuals and stirs them to action uniquely. 
In explaining the mechanism of students' integration into the scientific community, Estrada and colleagues contended that having research experience and receiving mentorship supports would positively improve students' academic performance, academic persistence, and their intention to pursue a scientific; while, it would negatively impact their intention to pursue a non-STEM research career (Estrada, 2014; and Estrada et al., 2018). Although our analysis revealed an increase in RAP participants' intention to pursue a scientific research career, it did not show any significant decrease in intention to pursue a humanity or medicine research career - partially consistent with Estrada and colleagues' works.

This study adds to the body of research showing the importance of having a faculty mentor (i.e., formal mentoring), especially in the long-term. Undergraduate students normally do not connect with their faculties outside the regular classes (Gates, 2019). Therefore, participating in RAP will help students create longer bonds with their faculties and integrate more into the academic community. Furthermore, RAP can boost students' identity as a scholarly researcher and improve their self-image. In summary, participation in RAP is recommended to expand students/faculties mentorship and improve students' self-image as a researcher.

\section{Limitations and Future Research}

Regarding TIMSI components to explain students' integration into the scientific community, this study only shows the unique mediation effect of research identity on the relationship between the RAP status and the long-term students' intention to pursue a scientific research career. However, this study has possible limitations that are needed to be addressed. The sample (with mostly White Americans) suffers from lack of diversity. Research has been conducted to examine the relationship between undergraduate research experiences and TIMSI components among specific ethnicities, such as African Americans and Hispanics; however, 
further research is needed to explore the effects in a more diverse community. Furthermore, this study has only explored the perceived, and not the real student intention variables. Even if some students show their intentions to pursue a research career, we cannot be sure if that intention would be strong enough to make them pursue a research career later. Further studies are needed to explore the graduated students' real intention to pursue a research career. Moreover, students were not survived before starting the program. As a result, we could not compare pre-surveys with post-surveys, which is an indicator of changes in students' perception due to their participation in the program (Hiebert et. al., 2011). Also, our data was only the results of students' opinions and performance. Regarding evaluating the impacts of RAP, as an intervention program, future studies could gather mentors and facilitators' opinions to have a better view of RAP achievements. 


\section{References:}

Aljohani, O. (2016). A comprehensive review of the major studies and theoretical models of student retention in higher education. Higher Education Studies, 6(2), 1-18. https://doi.org/10.5539/hes.v6n2p1

Azmitia, M., Syed, M., \& Radmacher, K. (2008). On the intersection of personal and social identities: Introduction and evidence from a longitudinal study of emerging adults. New Directions for Child and Adolescent Development, 120, 1-16. https://doi.org/10.1002/cd

Balster, N., Pfund, C., Rediske, R., \& Branchaw, J. (2010). Entering research: A course that creates community and structure for beginning undergraduate researchers in the STEM disciplines. CBE-Life Sciences Education, 9(2), 108-118. https://doi.org/10.1187/cbe.09

Bandura, A. (1997). Self-efficacy_ The exercise of control New York: Freeman. ISBN 0716726262.

Bangera, G., \& Brownell, S. E. (2014). Course-based undergraduate research experiences can make scientific research more inclusive. CBE_Life Sciences Education, 13(4), 602-606. https://doi.org/10.1187/cbe.14-06-0099

Barlow, A. E. L., \& Villarejo, M. (2004). Making a difference for minorities: Evaluation of an educational enrichment program. Journal of Research in Science Teaching, 41(9), 861-881. https://doi.org/10.1002/tea.20029

Bean, J. P. (1980). Dropouts and turnover: The synthesis and test of a causal model of student attrition. Research in Higher Education, 12(2), 155-187.

Berger, R. (2019). The problem with dropping out and why students leave school before 
graduating. International Journal of Psychological Research and Reviews, 2(9), 1-9. https://doi.org/10.28933/ijprr-2019-01-1005

Boykin, A. W. (1994). Harvesting talent and culture: African American children and educational reform. Schools and students at risk. In R. Rossi (Ed.). Schools and Students at Risk, 116138.

Braxton, J. M. (2019). Leaving college: Rethinking the causes and cures of student attrition by Vincent Tinto (review). Journal of College Student Development, 60(1), 129-134. https://doi.org/10.2307/40250027

Brower, A. M. (1992). The "second half" of student integration: The effects of life task predominance on student persistence. The Journal of Higher Education, 63(4), 441-462.

Burke, A. (2019). Student retention models in higher education : A literature review. College and University, 94(2), 12-21.

Byars-Winston, A., \& Rogers, J. G. (2019). Testing intersectionality of race/ethnicity $\times$ gender in a social-cognitive career theory model with science identity. Journal of Counseling Psychology, 66(1), 30-44. https://doi.org/10.1037/cou0000309.supp

Chance, R. C. (2013). Extensions of the tripartite integration model of social influence (timsi): Using explicit and implicit measures to examine ethnic minority and majority student academic achievement. Southern Illinois University at Carbondale. Chemers, M. M., Zurbriggen, E. L., Syed, M., Goza, B. K., \& Bearman, S. (2011). The role of efficacy and identity in science career commitment among underrepresented minority students. Journal of Social Issues, 67(3), 469-491. https://doi.org/10.1111/j.1540-4560.2011.01710.x 
Chen, X., \& Soldner, M. (2013). STEM attrition: College students' paths into and out of STEM fields. National Center for Education Statistics NCES.

Christensen, R., Knezek, G., \& Tyler-wood, T. (2014). Student perceptions of Science, Technology, Engineering and Mathematics ( STEM) content and careers. Computers in Human Behavior, 34, 173-186. https://doi.org/10.1016/j.chb.2014.01.046

Delen, D., Topuz, K., \& Eryarsoy, E. (2020). Development of a bayesian belief network-based DSS for predicting and understanding freshmen student attrition. European Journal of Operational Research, 281(3), 575-587.

DePass, A. L., \& Chubin, D. E. (2009). Understanding interventions that encourage minorities to pursue research careers: Building a community of research and practice. Summary of a conference, Atlanta, Georgia, May 2-4, 2008. American Society for Cell Biology.

Dreher, G. F., \& Ash, R. A. (1990). A comparative study of mentoring among men and women in managerial , professional , and technical positions. Journal of Applied Psychology, 75(5), $539-546$.

Eby, L. T. D. T., Allen, T. D., Hoffman, B. J., Baranik, L. E., Sauer, J. B., Baldwin, S., Morrison, M. A., Kinkade, K. M., Maher, C. P., Curtis, S., \& Evans, S. C. (2013). An interdisciplinary meta-analysis of the potential antecedents , correlates , and consequences of prote ' perceptions of mentoring. Psychological Bulletin, 139(2), 441-476. https://doi.org/10.1037/a0029279

Ensher, E. A., \& Murphy, S. E. (1997). Effects of race, gender, perceived similarity, and contact on mentor relationships. Journal of Vocational Behavior, 481(50), 460-481. 
Estrada, M., Hernandez, P. R., \& Schultz, P. W. (2018). A longitudinal study of how quality mentorship and research experience integrate underrepresented minorities into STEM careers. CBE—Life Sciences Education, 17(ar9), 1-13. https://doi.org/10.1187/cbe.17-040066

Estrada, M. (2014). Ingredients for improving the culture of STEM degree attainment with cocurricular supports for underrepresented minority students (Commissioned paper for National Academies of Science, Engineering and Medicine). 1-28.

Estrada, M., Woodcock, A., Hernandez, P. R., \& Schultz, P. W. (2011). Toward a model of social influence that explains minority student integration into the scientific community. Journal of Educational Psychology, 103(1), 206-222. https://doi.org/10.1037/a0020743

Farren, C. (2006). Eight Types of Mentors: Which ones do you need ? MasteryWorks. Inc., 1-7.

Faul, F., Erdfelder, E., Lance, A.-G., \& Buchner, A. (2007). G * Power 3 : A flexible statistical power analysis program for the social, behavioral, and biomedical sciences. Behavior Research Methods, 39(2), 175-191.

Feldman, A., Divoll, K. A., \& Rogan-klyve, A. (2013). Becoming researchers : The participation of undergraduate research groups. Science Education, 97(2), 218-243. https://doi.org/10.1002/sce.21051

Flaxman, E., Ascher, C., \& Harrington, C. (1988). Youth mentoring: Programs and practices. urban diversity series No. 97 .

Gates, A. (2019). Faculty interactions with Black male students at HBCUS and community colleges as predictors of academic achievement in STEM. 
GoCollege. (2019). Top 11 reasons why students drop out of college. Retrieved from http://blog.gocollege.com/2007/11/23/reasons-why-college-dropouts-exist/.

Gousse, K. V., Gawargi, F. I., Muralidharan, K., \& Hicks, M. J. (2019). Integration of authentic research into an undergraduate laboratory course: Design and synthesis of a gene therapy vector. The FASEB Journal, 33(1), 1-17.

Hamilton, V. L. (2004). The social psychology of group identity and social conflict: Theory, application, and practice (p. 65-. https://doi.org/https://doi.org/10.1037/10683-004

Harrison, K. C., Comeaux, E., Plecha, M., Harrison, K. C., Comeaux, E., Faculty, M. P., Harrison, C. K., Comeaux, E., \& Plecha, M. (2006). Faculty and male football and basketball players players on university campuses : An empirical investigation of the "intellectual" as mentor to the student athlete. Research Quarterly for Exercise and Sport, 1367. https://doi.org/10.1080/02701367.2006.10599361

Hathaway, R. S., Nagda, B. A., Gregerman, \& Gregerman, S. R. (2002). The relationship of undergraduate research participation to graduate and professional education pursuit: An empirical Study. Journal of College Student Development, 43(5), 614-631.

Hernandez, P. R., Estrada, M., Woodcock, A., \& Schultz, P. W. (2017). Mentor qualities that matter: The importance of perceived (not demographic) similarity. Journal of Experimental Psychology, 85(3), 450-468. https://doi.org/10.1016/j.physbeh.2017.03.040

Hernandez, P. R., Hopkins, P. D., Masters, K., Holland, L., Mei, B. M., Richards-Babb, M., Quedado, K., \& Shook, N. J. (2018). Student integration into STEM careers and culture: A longitudinal examination of summer faculty mentors and project ownership. CBE—Life Sciences Education, 17(3). 
Hernandez, P. R., Woodcock, A., Estrada, M., \& Schultz, W. (2018). Undergraduate research experiences broaden diversity in the scientific workforce. BioScience, 68(3), 204-211. https://doi.org/10.1093/biosci/bix 163

Hiebert, B., Bezanson, M. L., Magnusson, K., O'Reilly, E., Hopkins, S., \& McCaffrey, A. (2011). Assessing the impact of labour market information: Preliminary results of phase two (field tests). Final report to Human Resources and Skills Development Canada. Toronto: Canadian Career Development Foundation. Retrieved from http://www.crwggdrc.ca/crwg/index.php

Holt, D. T., Markova, G., Dhaenens, A. J., Marler, L. E., Heilmann, S. G., Journal, S., Summer, N. S., Holt, D. T., \& Dhaenens, A. J. (2016). Formal or informal mentoring : What drives employees to seek informal mentors?. Journal of Managerial Issues, 28(1), 67-82.

Johnson, N. (2012). The institutional costs of student attrition.

Judd, C. M., McClelland, G. H., \& Ryan, C. S. (2009). Outliers and ill-mannered error. In Data analysis: A model comparison approach (2nd edditi). New York, NY: Routledge.

Kelman, H. C. (1958). Compliance, identification, and internalization three processes of attitude change. Journal of Conflict Resolution, 2(1), 51-60.

Kelman, H. C. (2006). Interest, relationships, identities: Three central issues for individuals and groups in negotiating their social environment. Annu. Rev. Psychol, 57, 1-26. https://doi.org/10.1146/annurev.psych.57.102904.190156

Kram, K. E., \& Isabella, L. A. (1985). Mentoring alternatives: The role of peer relationships in career development. Academy of Management Journal, 28(1), 110-132. 
Laursen, S., Hunter, A., Seymour, E., Thiry, H., \& Melton, G. (2010). Undergraduate Research in the Sciences Engaging Students in Real Science.

Lent, R. W., Singley, D., Sheu, H., Schmidt, J. A., \& Schmidt, L. C. (2007). Relation of socialcognitive factors to academic satisfaction in engineering students. Journal of Career Assessment, 15(1), 87-97. https://doi.org/10.1177/1069072706294518

Linn, M. C., Palmer, E., Baranger, A., Gerard, E., \& Stone, E. (2015). Undergraduate research experiences: Impacts and opportunities. Review Summary, 347(6222). https://doi.org/10.1126/science.1261757

Little, R. J. A. (1988). A test of missing completely at random for multivariate data with missing values. Journal of the American Statistical Association, 83(404), 1198-1202.

Lopatto, D. (2003). The essential features of undergraduate research. Council on Undergraduate Research, 24, 139-142.

Maltese, A., Harsh, J., \& Jung, E. (2017). Evaluating undergraduate research experiencesdevelopment of a self-report tool. Education Sciences, 7(4), 87. https://doi.org/10.3390/educsci7040087

Martin-hansen, L. (2018). Examining ways to meaningfully support students in STEM. International Journal of STEM Education, 5(1), 1-7.

Mcallister, C. P., Iii, B. P. E., \& Ferris, G. R. (2018). Social influence opportunity recognition, evaluation, and capitalization: Increased theoretical specification through political skill's dimensional dynamics. Journal of Management, 44(5), 1926-1952. https://doi.org/10.1177/0149206316633747 
Millea, M., Wills, R., Elder, A., \& Molina, D. (2018). What matters in college student success? Determinants of college retention and graduation rates. Education, 138(4), 309-322.

Nagda, B. A., Gregman, S. R., Jonides, J., Hippel, W. von, \& Lerner, J. S. (1998). Undergraaduate student-faculty research partnerships affect student retention. The Review of Higher Education, 22(1).

Nakkula, M. J., \& Harris, J. T. (2005). Assessment of mentoring relationships. In In. D. L. DuBois \& M. J. Karcher (Eds.), Handbook of youth mentoring (pp. 100-117).

Nakkula, M. J., \& Harris, J. T. (2013). Assessing mentoring relationships. Handbook of youth mentoring (pp. 45-62).

NAS. (2017). Undergraduate research experiences for STEM students: Successes, challenges, and opportunities. National Academies Press.

Olivares-Donoso, R., \& González, C. (2019). Undergraduate research or research-based courses: Which is most beneficial for science students? Research in Science Education, 49(1), 91107. https://doi.org/10.1007/s11165-017-9616-4

Ommering, B. W. C., Diepen, M. Van, Blankenstein, F. M. Van, Jong, P. G. M. De, Dekker, F. W., Ommering, B. W. C., Diepen, M. Van, \& Blankenstein, F. M. Van. (2019). Twelve tips to offer a short authentic and experiential individual research opportunity to a large group of undergraduate students. Medical Teacher, 0(0), 1-6. https://doi.org/10.1080/0142159X.2019.1695766

Osborne, J. W., \& Walker, C. (2006). Stereotype threat, identification with academics, and withdrawal from school: Why the most successful students of colour might be most likely to 
withdraw. Educational Psychology, 26, 563-577.

Powers, L. E., Sowers, J., \& Stevens, T. (1995). An Exploratory, randomized study of the impact of mentoring on the self-efficacy and community-based knowledge of adolescents with severe physical challenges. Journal of Rehabilitation, 61(1), 33-42.

President's Council of Advisors on Science and Technology. (2012). Engage to excel: Producing one million additional college graduates with degrees in science, technology, engineering, and mathematics. Retrieved August 16, 2017, from https://obamawhitehouse.archives.gov/sites/ default/files/microsites/ostp/pcast-engage-toexcel-final_2-25-12.pdf

Quinn, J., Thomas, L., Slack, K., Casey, L., \& Thexton, W. (2005). From life crisis to lifelong learning. Re-thinking working class 'drop out'from higher education.

Ramist, L. (1981). College student attrition and retention. New York: College Entrance Examination Board.

Ritchey, K. D., Coker, D. L., \& Jackson, A. F. (2015). The relationship between early elementary teachers' instructional practices and theoretical orientations and students' growth in writing. Reading and Writing, 28(9), 1333-1354. https://doi.org/10.1007/s11145015-9573-0

Rodenbusch, S. E., Hernandez, P. R., Simmons, S. L., Dolan, E. L., Services, H., Hughes, H., \& Chase, C. (2016). Early engagement in course-based research increases graduation rates and completion of science, engineering, and mathematics degrees. Life Science Education, 15, 1-10. https://doi.org/10.1187/cbe.16-03-0117 
Rosenzweig, E. Q., Harackiewicz, J. M., Hecht, C. A., Priniski, S. J., Canning, E. A., Tibbetts, Y., Asher, M. W., \& Hyde, J. S. (2020). College students' reasons for leaving biomedical fields: Disenchantment with biomedicine or attraction to other fields? Journal of Educational Psychology. https://doi.org/10.1037/edu0000456

Russell, S. H., Hancock, M. P., \& Mccullough, J. (2007). Benefits of undergraduate research experiences. Science(Washington), 316(5824), 548-549.

Sadler, T. D., Burgin, S., Mckinney, L., Ponjuan, L., Education, C., Hall, N., \& Box, P. O. (2010). Learning science through research apprenticeships : A critical review of the literature. Journal of research in science teaching, 47(3), 235-256. https://doi.org/10.1002/tea.20326

Salinitri, G. (2005). The effects of formal mentoring on the retention rates for first-year, low achieving students. Canadian Journal of Education/Revue Canadienne de l'education, $28(4), 853-873$.

Schneider, M. (2010). Finishing the first lap: The cost of first year student attrition in America's four year colleges and universities. Washington, DC: American Institutes for Research. Retrieved from http://www.air.org/files/AIR_Schneider_Finishing_the_First_Lap_Oct10.pdf. American Institutes for Research, 1-17. http://www.air.org/files/AIR_Schneider_Finishing_the_First_Lap_Oct101.pdf

Schneider, M. (2011). The high cost of low graduation rates: How much does dropping out of college really cost? Washington, DC: American Institutes for Research.

Schultz, P. W., Hernandez, P. R., Woodcock, A., Estrada, M., Chance, R. C., Aguilar, M., \& 
Serpe, R. T. (2011). Patching the pipeline: Reducing educational disparities in the sciences through minority training programs. Educational Evaluation and Policy Analysis, 33(1),

Sciences, N. A. of. (2005). Assessment of NIH minority research and training programs: Phase 3. National Academies Press.

Shrout, P. E., \& Bolger, N. (2002). Mediation in experimental and nonexperimental studies : New procedures and recommendations. Psychological Methods, 7(4), 422-445. https://doi.org/10.1037//1082-989X.7.4.422

Spady, W. G. (1971). Dropouts from higher education: An interdisciplinary review and synthesis. Interchange, 2(3), 38-62.

Stajkovic, A. D., \& Luthans, F. (1998). Self-efficacy and work-related performance: A metaanalysis. Psychological Bulletin, 124(2), 240-261.

Stets, J. E., P.S., B., Burke, P. J., \& Serpe, R. T. (2017). The science identity and entering a science occupation. Social Science Research, 64(1), 1-14.

Strawn, C., \& Livelybrooks, D. (2012). A five-year university/community college collaboration to build STEM pipeline capacity. Journal of College Science Teaching, 41(6), 47-51.

Syed, M., Zurbriggen, E. L., Chemers, M. M., Goza, B. K., Bearman, S., Crosby, F. J., Shaw, J. M., Hunter, L., \& Morgan, E. M. (2019). The role of self-efficacy and identity in mediating the effects of STEM support experiences. Analyses of Social Issues and Public Policy, 19(1), 7-49.

Taylor, A. Z., \& Graham, S. (2007). An examination of the relationship between achievement values and perceptions of barriers among low-SES African American and Latino Students. 
Journal of Educational Psychology, 99(1), 52-64. https://doi.org/10.1037/00220663.99 .1 .52

Tenenbau m, H. R., Crosby, F. J., \& Gliner, M. D. (2001). Mentoring relationships in graduate school. Journal of Vocational Behavior, 59, 326-341. https://doi.org/10.1006/jvbe.2001.1804

Thiry, H., Laursen, S. L., Hunter, A., Taylor, P., Thiry, H., Laursen, S. L., \& Hunter, A. (2011). What experiences help students become scientists? A comparative study of research and other sources of personal and professional gains for STEM undergraduates. Journal of Higher Education, 82(4), 357-388.

Thompson, L. A., \& Kelly-vance, L. (2001). The impact of mentoring on academic achievement of at-risk youth. Children AndYouth Services Review, 23(3), 227-242.

Tinto, V. (1987). Leaving college: Rethinking the causes and cures of student attrition. University of Chicago Press, 5801 S. Ellis Avenue, Chicago, IL 60637.

University of Chicago. (n.d.) College center for research and fellowship. Retrieved April 4, 2020, from https://ccrf.uchicago.edu/.

White, A. M., DeCuir-Gunby, J. T., \& Kim, S. (2019). A mixed methods exploration of the relationships between the racial identity, science identity, science self-efficacy, and science achievement of African American students at HBCUs. Contemporary Educational Psychology, 57, 54-71.

Woodcock, A., Hernandez, P. R., \& Schultz, P. W. (2015). Diversifying Science: Intervention Programs Moderate the Effect of Stereotype Threat on Motivation and Career Choice. Soc 
Psychol Personal Sci, 7(2), 184-192.

https://doi.org/10.1177/1948550615608401.Diversifying 


\section{Tables and Figure}

Table 1. Descriptive statistics of RAP and non-RAP students

\begin{tabular}{|c|c|c|c|c|c|}
\hline & \multicolumn{2}{|c|}{$R A P$} & \multicolumn{2}{|c|}{ Control } \\
\hline & & Number & Percentage & Number & Percentage \\
\hline \multirow[t]{2}{*}{ Gender } & Female & 97 & $\sim 70 \%$ & 117 & $\sim 75 \%$ \\
\hline & Male & 41 & $\sim 30 \%$ & 38 & $\sim 25 \%$ \\
\hline Race/ & White & 117 & $\sim 85 \%$ & 127 & $\sim 82 \%$ \\
\hline \multirow[t]{4}{*}{ Ethnicity } & Hispanics & 7 & $\sim 5 \%$ & 7 & $\sim 4 \%$ \\
\hline & Asian & 3 & $\sim 2 \%$ & 6 & $\sim 4 \%$ \\
\hline & African American & 8 & $\sim 6 \%$ & 5 & $\sim 3 \%$ \\
\hline & Two or more & 3 & $\sim 2 \%$ & 8 & $\sim 5 \%$ \\
\hline \multirow[t]{9}{*}{ Major } & Biology/life Science & 36 & $\sim 26 \%$ & 33 & $\sim 21 \%$ \\
\hline & Social/Behavioral & 24 & $\sim 17 \%$ & 36 & $\sim 23 \%$ \\
\hline & Engineering & 23 & $\sim 17 \%$ & 21 & $\sim 13 \%$ \\
\hline & Humanities/Liberal Arts & 14 & $\sim 10 \%$ & 26 & $\sim 17 \%$ \\
\hline & Agricultural Science & 10 & $\sim 7 \%$ & 10 & $7 \%$ \\
\hline & Business & 4 & $\sim 3 \%$ & 8 & $\sim 5 \%$ \\
\hline & Health/Human Science & 8 & $\sim 6 \%$ & 10 & $\sim 7 \%$ \\
\hline & Math/Computer & 10 & $\sim 7 \%$ & 2 & $\sim 1 \%$ \\
\hline & Natural Science & 3 & $\sim 2 \%$ & 3 & $\sim 2 \%$ \\
\hline College & Freshmen & 61 & $\sim 44 \%$ & 57 & $\sim 37 \%$ \\
\hline \multirow[t]{3}{*}{ Rank } & Sophomores & 42 & $\sim 30 \%$ & 50 & $\sim 32 \%$ \\
\hline & Junior & 23 & $\sim 17 \%$ & 29 & $\sim 19 \%$ \\
\hline & Senior & 12 & $\sim 9 \%$ & 19 & $\sim 12 \%$ \\
\hline \multirow[t]{2}{*}{ Generation } & First generation & 55 & $\sim 40 \%$ & 58 & $\sim 37 \%$ \\
\hline & Second generation & 83 & $\sim 60 \%$ & 97 & $\sim 63 \%$ \\
\hline
\end{tabular}


Table 2. Descriptive statistics for mentoring, psychological mediators, and outcomes of interest as a function of group status

\begin{tabular}{|c|c|c|c|c|c|c|c|c|c|c|}
\hline \multirow[b]{2}{*}{ Variables } & \multicolumn{5}{|c|}{$R A P$} & \multicolumn{5}{|c|}{ Control } \\
\hline & $N$ & $M$ & $S D$ & Skew. & $K$. & $N$ & $M$ & $S D$ & Skew. & $K$. \\
\hline $\begin{array}{l}\text { 1.Mentor } \\
\text { satisfaction (T1) }\end{array}$ & 121 & 6.03 & 1.04 & -1.38 & 2.24 & 67 & 5.88 & 1.22 & -1.19 & 1.58 \\
\hline $\begin{array}{l}\text { 2.Psycho. support } \\
\text { (T1) }\end{array}$ & 122 & 5.25 & 1.36 & -0.64 & -0.17 & 66 & 5.13 & 1.30 & -0.52 & 0.14 \\
\hline $\begin{array}{l}\text { 3.Instrumental } \\
\text { support (T1) }\end{array}$ & 122 & 4.92 & 1.25 & -0.61 & 0.37 & 67 & 4.98 & 1.40 & -0.71 & 0.44 \\
\hline $\begin{array}{l}\text { 4.Network diversity } \\
\text { (T1) }\end{array}$ & 110 & 2.27 & 1.64 & 0.55 & -0.35 & 130 & 2.05 & 1.67 & 0.65 & -0.28 \\
\hline $\begin{array}{l}\text { 5.Having faculty } \\
\text { mentor (T1)* }\end{array}$ & 115 & 0.90 & 0.31 & - & - & 143 & 0.47 & 0.50 & - & - \\
\hline $\begin{array}{l}\text { 6.Mentor } \\
\text { satisfaction (T2) }\end{array}$ & 92 & 6.07 & 1.09 & -1.25 & 1.46 & 44 & 6.04 & 0.93 & -0.69 & -0.69 \\
\hline $\begin{array}{l}\text { 7.Psycho. support } \\
\text { (T2) }\end{array}$ & 91 & 5.19 & 1.41 & -0.64 & 0.17 & 43 & 5.30 & 1.06 & -0.11 & -0.68 \\
\hline $\begin{array}{l}\text { 8.Instrumental } \\
\text { support (T2) }\end{array}$ & 91 & 5.38 & 1.20 & -1.13 & 1.27 & 43 & 5.24 & 0.99 & -0.35 & -0.19 \\
\hline $\begin{array}{l}\text { 9. Network diversity } \\
\text { (T2) }\end{array}$ & 86 & 2.51 & 1.63 & 0.38 & 0.00 & 88 & 2.03 & 1.89 & 0.75 & -0.26 \\
\hline $\begin{array}{l}\text { 10.Having faculty } \\
\text { mentor (T2)* }\end{array}$ & 91 & 0.95 & 0.23 & - & - & 98 & 0.45 & 0.50 & - & - \\
\hline $\begin{array}{l}\text { 11.Research self- } \\
\text { efficacy (T1) }\end{array}$ & 135 & 4.72 & 1.14 & -0.21 & 0.09 & 135 & 4.28 & 1.33 & -0.44 & 0.24 \\
\hline $\begin{array}{l}\text { 12.Research } \\
\text { identity (T1) }\end{array}$ & 133 & 4.25 & 1.54 & -0.17 & -0.60 & 136 & 3.19 & 1.65 & 0.46 & -0.74 \\
\hline $\begin{array}{l}\text { 13.Community obj. } \\
\text { value (T1) }\end{array}$ & 134 & 6.10 & 0.99 & -1.30 & 1.40 & 136 & 5.38 & 1.40 & -0.70 & -0.40 \\
\hline $\begin{array}{l}\text { 14. Research self- } \\
\text { efficacy (T2) }\end{array}$ & 99 & 5.03 & 1.18 & 0.00 & -0.52 & 97 & 4.56 & 1.29 & -0.47 & 0.01 \\
\hline $\begin{array}{l}\text { 15.Research } \\
\text { identity (T2) }\end{array}$ & 99 & 4.57 & 1.63 & -0.30 & -0.66 & 97 & 3.08 & 1.68 & 0.59 & -0.42 \\
\hline $\begin{array}{l}\text { 16.Community obj. } \\
\text { value (T2) }\end{array}$ & 99 & 6.10 & 1.03 & -1.16 & 0.87 & 95 & 5.43 & 1.34 & -0.80 & 0.52 \\
\hline $\begin{array}{l}\text { 17.Intention_STEM } \\
\text { (T1) }\end{array}$ & 134 & 6.45 & 3.27 & -0.87 & -0.49 & 131 & 5.06 & 3.40 & -0.25 & -1.26 \\
\hline $\begin{array}{l}\text { 18.Intention_MED } \\
\text { (T1) }\end{array}$ & 135 & 3.91 & 4.11 & 0.40 & -1.60 & 132 & 3.23 & 3.60 & 0.66 & -1.06 \\
\hline $\begin{array}{l}\text { 19.Intention_HUM } \\
\text { (T1) }\end{array}$ & 133 & 2.99 & 3.21 & 0.69 & -0.92 & 132 & 3.46 & 3.10 & 0.58 & -0.73 \\
\hline $\begin{array}{l}\text { 20.Intention_STEM } \\
\text { (T2) }\end{array}$ & 99 & 6.23 & 3.26 & -0.73 & -0.63 & 97 & 4.85 & 3.36 & -0.13 & -1.27 \\
\hline $\begin{array}{l}\text { 21.Intention_MED } \\
\text { (T2) }\end{array}$ & 99 & 3.20 & 3.97 & 0.81 & -1.05 & 96 & 2.85 & 3.66 & 0.94 & -0.74 \\
\hline
\end{tabular}




\begin{tabular}{|c|c|c|c|c|c|c|c|c|c|c|}
\hline $\begin{array}{l}\text { 22.Intention_HUM } \\
\text { (T2) }\end{array}$ & 98 & 2.71 & 3.28 & 0.85 & -0.77 & 95 & 3.13 & 3.12 & 0.69 & -0.79 \\
\hline $\begin{array}{l}\text { 23.Cumulative } \\
\text { GPA }\end{array}$ & 137 & 3.31 & 0.48 & -0.77 & 0.64 & 152 & 3.21 & 0.57 & -0.86 & 1.26 \\
\hline $\begin{array}{l}\text { 24.Academic } \\
\text { persistence }\end{array}$ & 137 & 0.85 & 0.36 & -1.95 & 1.81 & 155 & 0.81 & 0.39 & -1.62 & 0.63 \\
\hline
\end{tabular}

Notes: $\mathrm{N}=$ number, $\mathrm{M}=$ mean, $\mathrm{SD}=$ standard deviation, Skew $=$ skewness, $\mathrm{K} .=$ kurtosis, Psycho. Support $=$ psychosocial support, Intention_STEM = Intentions to pursue a scientific research career, Intention_MED = Intentions to pursue a medicine research career, Intention_HUM = Intentions to pursue a humanity research career; Higher values of Mean represent higher responses. ${ }^{*}$ Having faculty mentor is a binary variable. 
Table 3. Correlation matrix of the relationships among RAP status, mentoring, psychological mediators, and outcomes of interest

\begin{tabular}{|c|c|c|c|c|c|c|c|c|c|c|}
\hline & 1 & 2 & 3 & 4 & 5 & 6 & 7 & 8 & 9 & 10 \\
\hline 1.Mentor satisfaction (T1) & 1 & & & & & & & & & \\
\hline 2.Psychosocial (T1) & $0.50 * *$ & 1 & & & & & & & & \\
\hline 3.Instrumental (T1) & $0.60 * *$ & $0.59 * *$ & 1 & & & & & & & \\
\hline 4.Network diversity (T1) & 0.04 & 0.06 & 0.04 & 1 & & & & & & \\
\hline 5.Having faculty mentor (T1) & $0.18 * *$ & 0.09 & 0.08 & $0.25 * *$ & 1 & & & & & \\
\hline 6.Mentor satisfaction (T2) & $0.42 * *$ & $0.25 * *$ & $0.31 * *$ & 0.02 & 0.09 & 1 & & & & \\
\hline 7.Psychosocial (T2) & $0.23 *$ & $0.43 * *$ & $0.28 * *$ & -0.00 & -0.01 & $0.59 * *$ & 1 & & & \\
\hline 8.Instrumental (T2) & $0.25 * *$ & $0.21 *$ & $0.37 * *$ & 0.03 & 0.04 & $0.62 * *$ & $0.63 * *$ & 1 & & \\
\hline 9.Network diversity (T2) & 0.06 & -0.03 & 0.00 & $0.45^{* *}$ & $0.20 * *$ & 0.10 & -0.04 & -0.07 & 1 & \\
\hline 10.Having faculty mentor (T2) & $0.22 * *$ & 0.11 & 0.16 & $0.18 *$ & $0.53 * *$ & $\mathrm{c}$ & $\mathrm{c}$ & $\mathrm{c}$ & $0.18 *$ & 1 \\
\hline 11.Self-efficay (T1) & $0.21 * *$ & $0.18 *$ & $0.27 * *$ & 0.09 & $0.22 * *$ & 0.06 & 0.08 & $0.20 *$ & 0.01 & $0.21 * *$ \\
\hline 12.Science-identity (T1) & $0.26 * *$ & $0.15^{*}$ & $0.26 * *$ & 0.11 & $0.34 * *$ & 0.05 & 0.13 & $0.23 * *$ & 0.01 & $0.34 * *$ \\
\hline 13.Community (T1) & $0.31 * *$ & $0.14 *$ & $0.22 * *$ & 0.07 & $0.29 * *$ & $0.22 *$ & $0.22 *$ & $0.22 *$ & 0.05 & $0.26^{* *}$ \\
\hline 14.Self-efficay (T2) & 0.17 & 0.17 & $0.19 *$ & 0.09 & $0.15^{*}$ & $0.37 * *$ & $0.31 * *$ & $0.37 * *$ & 0.12 & $0.28 * *$ \\
\hline 15.Science-identity (T2) & $0.25 * *$ & 0.06 & 0.17 & 0.03 & $0.25 * *$ & $0.23 * *$ & $0.30 * *$ & $0.36^{* *}$ & $0.22 * *$ & $0.41 * *$ \\
\hline 16.Community (T2) & $0.26^{* *}$ & 0.03 & 0.14 & 0.06 & $0.21 * *$ & $0.34 * *$ & $0.24 * *$ & $0.30 * *$ & 0.08 & $0.27 * *$ \\
\hline 17.Intention_STEM (T1) & 0.03 & -0.06 & -0.01 & 0.11 & $0.20 * *$ & -0.01 & 0.04 & 0.10 & 0.04 & $0.17 *$ \\
\hline 18.Intention_MED (T1) & 0.00 & 0.06 & 0.02 & $0.12 *$ & 0.05 & 0.10 & $0.23 * *$ & 0.15 & 0.13 & -0.11 \\
\hline 19.Intention_HUM (T1) & 0.06 & 0.07 & 0.11 & -0.07 & -0.06 & -0.07 & 0.01 & -0.06 & -0.07 & -0.12 \\
\hline 20.Intention_STEM (T2) & 0.09 & -0.02 & 0.05 & 0.08 & 0.11 & 0.11 & 0.12 & 0.11 & $0.18 *$ & 0.14 \\
\hline 21.Intention_MED (T2) & -0.00 & 0.12 & -0.00 & 0.04 & -0.01 & 0.10 & $0.18 *$ & $0.17 *$ & $0.15^{*}$ & $-0.16^{*}$ \\
\hline 22.Intention_HUM (T2) & -0.04 & 0.04 & 0.05 & -0.08 & $-0.15^{*}$ & 0.09 & $0.20 *$ & 0.13 & 0.02 & -0.00 \\
\hline 23.High school GPA & 0.00 & -0.04 & -0.14 & 0.05 & 0.01 & 0.09 & 0.09 & -0.00 & 0.10 & 0.05 \\
\hline 24. Rank & 0.07 & 0.09 & 0.13 & 0.00 & 0.08 & 0.11 & 0.15 & 0.17 & -0.11 & 0.03 \\
\hline 25. Major & -0.10 & -0.11 & -0.03 & -0.09 & -0.11 & 0.04 & -0.04 & -0.07 & $-0.20 * *$ & 0.04 \\
\hline 26. Cohort & 0.05 & -0.02 & 0.05 & -0.10 & -0.09 & 0.01 & -0.05 & 0.05 & 0.01 & 0.09 \\
\hline 27. Cum. GPA & 0.09 & 0.00 & 0.00 & $0.16^{* *}$ & 0.05 & 0.01 & -0.12 & 0.03 & 0.13 & $0.27 * *$ \\
\hline 28. Academic persistence & 0.02 & -0.07 & -0.03 & 0.09 & -0.00 & -0.02 & -0.07 & -0.03 & 0.12 & 0.11 \\
\hline 29.RAP & 0.06 & 0.04 & -0.02 & 0.07 & $0.45 * *$ & 0.01 & -0.03 & 0.06 & 0.13 & $0.53 * *$ \\
\hline
\end{tabular}

Notes: **. Correlation is significant at the 0.01 level; *. Correlation is significant at the 0.05 level. 
Table 3

Continued

\begin{tabular}{|c|c|c|c|c|c|c|c|c|c|c|}
\hline & 11 & 12 & 13 & 14 & 15 & 16 & 17 & 18 & 19 & 20 \\
\hline 11.Self-efficay (T1) & 1 & & & & & & & & & \\
\hline 12.Science-identity (T1) & $0.50 * *$ & 1 & & & & & & & & \\
\hline 13.Community (T1) & $0.28 * *$ & $0.52 * *$ & 1 & & & & & & & \\
\hline 14.Self-efficay (T2) & $0.42 * *$ & $0.33 * *$ & $0.37 * *$ & 1 & & & & & & \\
\hline 15.Science-identity (T2) & $0.32 * *$ & $0.61 * *$ & $0.44 * *$ & $0.50 * *$ & 1 & & & & & \\
\hline 16.Community (T2) & $0.23 * *$ & $0.39 * *$ & $0.55^{* *}$ & $0.42 * *$ & $0.50 * *$ & 1 & & & & \\
\hline 17.Intention_STEM (T1) & $0.18 * *$ & $0.31 * *$ & $0.32 * *$ & 0.10 & $0.31 * *$ & $0.21 * *$ & 1 & & & \\
\hline 18.Intention_MED (T1) & 0.07 & $0.15^{*}$ & $0.19 * *$ & -0.07 & 0.07 & $0.15^{*}$ & $0.46 * *$ & 1 & & \\
\hline 19.Intention_HUM (T1) & $0.16 * *$ & $0.17 * *$ & 0.04 & 0.07 & -0.00 & 0.02 & $-0.32 *$ & -0.03 & 1 & \\
\hline 20.Intention_STEM (T2) & 0.02 & $0.17 *$ & $0.23 * *$ & $0.22 * *$ & $0.44 * *$ & $0.33 * *$ & $0.69 * *$ & $0.31 * *$ & $-0.30 *$ & 1 \\
\hline 21.Intention_MED (T2) & -0.00 & 0.05 & 0.13 & -0.05 & 0.10 & $0.17 *$ & $0.28 * *$ & $0.80 * *$ & -0.10 & $0.36 * *$ \\
\hline 22.Intention_HUM (T2) & 0.12 & -0.05 & 0.04 & 0.11 & 0.03 & 0.04 & $-0.45^{*}$ & $-0.20 *$ & $0.69 * *$ & $-0.40 * *$ \\
\hline 23.High school GPA & -0.01 & 0.02 & $0.14 *$ & -0.00 & -0.03 & 0.04 & $0.26 * *$ & 0.11 & $-0.19 * *$ & $0.18 *$ \\
\hline 24. Rank & 0.11 & 0.05 & -0.00 & 0.08 & 0.07 & 0.10 & -0.02 & -0.05 & -0.07 & 0.04 \\
\hline 25. Major & 0.08 & -0.02 & $-0.13^{*}$ & 0.02 & -0.02 & 0.02 & $-0.14 *$ & $-0.22 * *$ & $0.31 * *$ & -0.13 \\
\hline 26. Cohort & -0.04 & -0.00 & 0.00 & 0.13 & $0.19 * *$ & 0.12 & -0.02 & -0.08 & 0.01 & 0.13 \\
\hline 27. Cum. GPA & 0.06 & 0.07 & 0.06 & -0.02 & 0.08 & 0.09 & $0.13 *$ & 0.10 & -0.04 & 0.08 \\
\hline 28. Academic persistence & $-0.12 *$ & -0.05 & -0.01 & -0.08 & 0.06 & 0.01 & 0.04 & -0.06 & -0.10 & 0.13 \\
\hline 29.RAP & $0.17 * *$ & $0.31 * *$ & $0.28 * *$ & $0.19 * *$ & $0.41 * *$ & $0.27 * *$ & $0.21 * *$ & 0.09 & -0.07 & $0.20 * *$ \\
\hline
\end{tabular}

Notes: **. Correlation is significant at the 0.01 level; *. Correlation is significant at the 0.05 level. 
Table 3

Continued

\begin{tabular}{|c|c|c|c|c|c|c|c|c|c|}
\hline & 21 & 22 & 23 & 24 & 25 & 26 & 27 & 28 & 29 \\
\hline 21.Intention_MED (T2) & 1 & & & & & & & & \\
\hline 22.Intention_HUM (T2) & $-0.16^{*}$ & 1 & & & & & & & \\
\hline 23.High school GPA & 0.11 & -0.10 & 1 & & & & & & \\
\hline 24. Rank & 0.07 & 0.05 & -0.07 & 1 & & & & & \\
\hline 25. Major & $-0.26 * *$ & $0.35 * *$ & -0.11 & 0.10 & 1 & & & & \\
\hline 26. Cohort & -0.05 & 0.01 & -0.08 & 0.06 & 0.09 & 1 & & & \\
\hline 27. Cum. GPA & 0.07 & -0.11 & $0.44 *$ & 0.10 & -0.07 & 0.00 & 1 & & \\
\hline 28. Academic persistence & -0.03 & -0.11 & $0.17 * *$ & $-0.25 * *$ & -0.06 & -0.02 & $0.28 * *$ & 1 & \\
\hline 29.RAP & 0.05 & -0.07 & -0.00 & -0.08 & -0.05 & 0.03 & 0.09 & 0.04 & 1 \\
\hline
\end{tabular}

Notes: **. Correlation is significant at the 0.01 level; *. Correlation is significant at the 0.05 level. 
Table 4. Summary of logistic regression predicting mentoring and academic persistence as a function of RAP status

\begin{tabular}{|c|c|c|c|c|c|c|}
\hline & Source & $b$ & $S E$ & Wald $\chi^{2}(1)$ & $\exp (b)$ & $95 \%$ C.I. \\
\hline \multirow[t]{6}{*}{$\mathrm{T} 1$} & Having a faculty mentor & 2.46 & 0.38 & $42.98 * *$ & 11.77 & {$[5.63,24.59]$} \\
\hline & Major & -0.10 & 0.05 & 3.67 & 0.90 & {$[0.80,1.00]$} \\
\hline & High school GPA & 0.10 & 0.34 & 0.09 & 1.10 & {$[0.57,2.16]$} \\
\hline & Race & -0.11 & 0.10 & 1.39 & 0.89 & {$[0.74,1.08]$} \\
\hline & Rank & 0.44 & 0.16 & $7.56^{* *}$ & 1.56 & {$[1.14,2.14]$} \\
\hline & Cohort & -0.23 & 0.17 & 1.90 & 0.79 & {$[0.57,1.10]$} \\
\hline \multirow[t]{6}{*}{$\mathrm{T} 2$} & Having a faculty mentor & 3.23 & 0.53 & $36.71 * *$ & 25.25 & {$[8.88,71.77]$} \\
\hline & Major & 0.03 & 0.07 & 0.25 & 1.03 & {$[0.90,1.18]$} \\
\hline & High school GPA & 0.65 & 0.48 & 1.83 & 1.91 & {$[0.75,4.88]$} \\
\hline & Race & -0.00 & 0.11 & 0.00 & 0.99 & {$[0.80,1.24]$} \\
\hline & Rank & 0.43 & 0.20 & $4.53 *$ & 1.53 & {$[1.03,2.27]$} \\
\hline & Cohort & 0.24 & 0.21 & 1.34 & 1.27 & {$[0.85,1.91]$} \\
\hline \multirow[t]{6}{*}{$\mathrm{T} 2$} & Academic persistence & 0.52 & 0.39 & 1.79 & 1.68 & {$[0.78,3.60]$} \\
\hline & Major & -0.01 & 0.06 & 0.02 & 0.99 & {$[0.88,1.12]$} \\
\hline & High school GPA & 0.75 & 0.37 & $4.06 *$ & 2.12 & {$[1.02,4.39]$} \\
\hline & Race & -0.04 & 0.12 & 0.10 & 0.96 & {$[0.76,1.22]$} \\
\hline & Rank & 0.43 & 1.76 & 0.06 & 1.54 & {$[0.38,0.74]$} \\
\hline & Cohort & 0.07 & 0.19 & 0.12 & 1.07 & {$[0.73,1.56]$} \\
\hline
\end{tabular}

Notes: **. Correlation is significant at the 0.01 level; *. Correlation is significant at the 0.05 level. 
Table 5. Summary of regression analyses predicting short-term mentorship-related outcomes from RAP, controlling for background characteristics

\begin{tabular}{|c|c|c|c|c|c|c|c|c|c|}
\hline \multirow[b]{3}{*}{ Source } & & \multicolumn{8}{|c|}{ Dependent Variables } \\
\hline & & \multicolumn{2}{|c|}{ Satisfaction } & \multicolumn{2}{|c|}{ Psychosocial Support } & \multicolumn{2}{|c|}{ Instrumental Support } & \multicolumn{2}{|c|}{$\begin{array}{c}\text { Mentor Network } \\
\text { Diversity }\end{array}$} \\
\hline & & $\begin{array}{c}B \\
95 \% C I \\
\end{array}$ & $S E$ & $\begin{array}{c}B \\
95 \% C I \\
\end{array}$ & $S E$ & $\begin{array}{c}B \\
95 \% C I \\
\end{array}$ & $S E$ & $\begin{array}{c}B \\
95 \% C I\end{array}$ & $S E$ \\
\hline Intercept & & $\begin{array}{c}11.39 \\
{[0.59,22.20]}\end{array}$ & 1.13 & $\begin{array}{c}13.51 \\
{[0.01,27.0]}\end{array}$ & 6.76 & $\begin{array}{c}16.42 \\
{[31.68,1.16]}\end{array}$ & 7.64 & $\begin{array}{c}10.30 \\
{[-9.47,30.07]}\end{array}$ & 9.89 \\
\hline RAP & & $\begin{array}{c}0.38 \\
{[-.21, .98]}\end{array}$ & 0.30 & $\begin{array}{c}0.42 \\
{[-0.31,1.15]}\end{array}$ & 0.37 & $\begin{array}{c}0.16 \\
{[-0.67,0.99]}\end{array}$ & 0.42 & $\begin{array}{c}-0.45 \\
{[-1.08,0.18]}\end{array}$ & 0.32 \\
\hline $\begin{array}{l}\text { High school } \\
\text { GPA }\end{array}$ & & $\begin{array}{c}-0.34 \\
{[-0.97,0.30]}\end{array}$ & 0.32 & $\begin{array}{c}-0.54 \\
{[-0.23,1.33]}\end{array}$ & 0.40 & $\begin{array}{c}-0.63 \\
{[-0.26,1.52]}\end{array}$ & 0.45 & $\begin{array}{c}-0.38 \\
{[-1.51,0.75]}\end{array}$ & 0.56 \\
\hline Cohort 1 & & $\begin{array}{c}-0.17 \\
{[-0.68,0.33]}\end{array}$ & 0.25 & $\begin{array}{c}0.05 \\
{[-0.57,0.68]}\end{array}$ & 0.31 & $\begin{array}{c}-0.19 \\
{[-0.90,0.51]}\end{array}$ & 0.35 & $\begin{array}{c}-8.90 \\
{[-9.79,-8.01]}\end{array}$ & 0.44 \\
\hline Cohort 2 & & $\begin{array}{c}-0.57 \\
{[-1.78,0.64]}\end{array}$ & 0.61 & $\begin{array}{c}-1.05 \\
{[-2.55,0.46]}\end{array}$ & 0.75 & $\begin{array}{c}-1.03 \\
{[-2.73,0.67]}\end{array}$ & 0.85 & $\begin{array}{c}0.55 \\
{[-1.55,2.64]}\end{array}$ & 1.05 \\
\hline \multirow[t]{8}{*}{ Major } & Agriculture & $\begin{array}{c}0.99 \\
{[-0.25,2.24]}\end{array}$ & 0.62 & $\begin{array}{c}-0.60 \\
{[-2.16,0.97]}\end{array}$ & 0.78 & $\begin{array}{c}0.78 \\
{[-0.99,2.54]}\end{array}$ & 0.88 & $\begin{array}{c}-0.40 \\
{[-2.55,1.75]}\end{array}$ & 1.08 \\
\hline & Biology & $\begin{array}{c}0.76 \\
{[-0.11,1.63]}\end{array}$ & 0.47 & $\begin{array}{c}0.99 \\
{[-0.10,2.08]}\end{array}$ & 0.55 & $\begin{array}{c}1.04 \\
{[-0.19,2.27]}\end{array}$ & 0.62 & $\begin{array}{c}-0.24 \\
{[-1.78,1.29]}\end{array}$ & 0.79 \\
\hline & Business & $\begin{array}{c}1.29 \\
{[-0.14,2.72]}\end{array}$ & 0.72 & $\begin{array}{c}1.67 \\
{[-0.11,3.46]}\end{array}$ & 0.90 & $\begin{array}{c}2.56 \\
{[0.54,4.58]}\end{array}$ & 1.01 & $\begin{array}{c}-3.19 \\
{[-5.63,0.75]}\end{array}$ & 1.22 \\
\hline & Engineering & $\begin{array}{c}0.23 \\
{[-0.69,1.14]}\end{array}$ & 0.46 & $\begin{array}{c}0.28 \\
{[-0.86,1.42]}\end{array}$ & 0.57 & $\begin{array}{c}0.53 \\
{[-0.76,1.82]}\end{array}$ & 0.65 & $\begin{array}{c}-0.87 \\
{[-2.05,0.76]}\end{array}$ & 0.82 \\
\hline & Health/Human & $\begin{array}{c}0.07 \\
{[-2.05,2.19]}\end{array}$ & 1.06 & $\begin{array}{c}0.49 \\
{[-2.16,3.13]}\end{array}$ & 1.32 & $\begin{array}{c}-0.61 \\
{[-3.60,2.38]}\end{array}$ & 1.50 & $\begin{array}{c}1.79 \\
{[-1.77,5.36]}\end{array}$ & 1.79 \\
\hline & Liberal Arts & $\begin{array}{c}0.85 \\
{[-0.03,1.99]}\end{array}$ & 0.57 & $\begin{array}{c}0.90 \\
{[-0.46,2.26]}\end{array}$ & 0.68 & $\begin{array}{c}0.80 \\
{[-0.74,2.33]}\end{array}$ & 0.77 & $\begin{array}{c}-1.32 \\
{[-3.34,0.07]}\end{array}$ & 1.01 \\
\hline & Natural Science & $\begin{array}{c}0.77 \\
{[-0.72,2.27]}\end{array}$ & 0.75 & $\begin{array}{c}0.22 \\
{[-2.08,1.65]}\end{array}$ & 0.93 & $\begin{array}{c}0.97 \\
{[-1.13,3.08]}\end{array}$ & 1.06 & $\begin{array}{c}-0.20 \\
{[-2.73,2.37]}\end{array}$ & 1.27 \\
\hline & Social Science & 0.46 & 0.51 & 1.06 & 0.63 & 0.96 & 0.71 & -0.16 & 0.88 \\
\hline
\end{tabular}




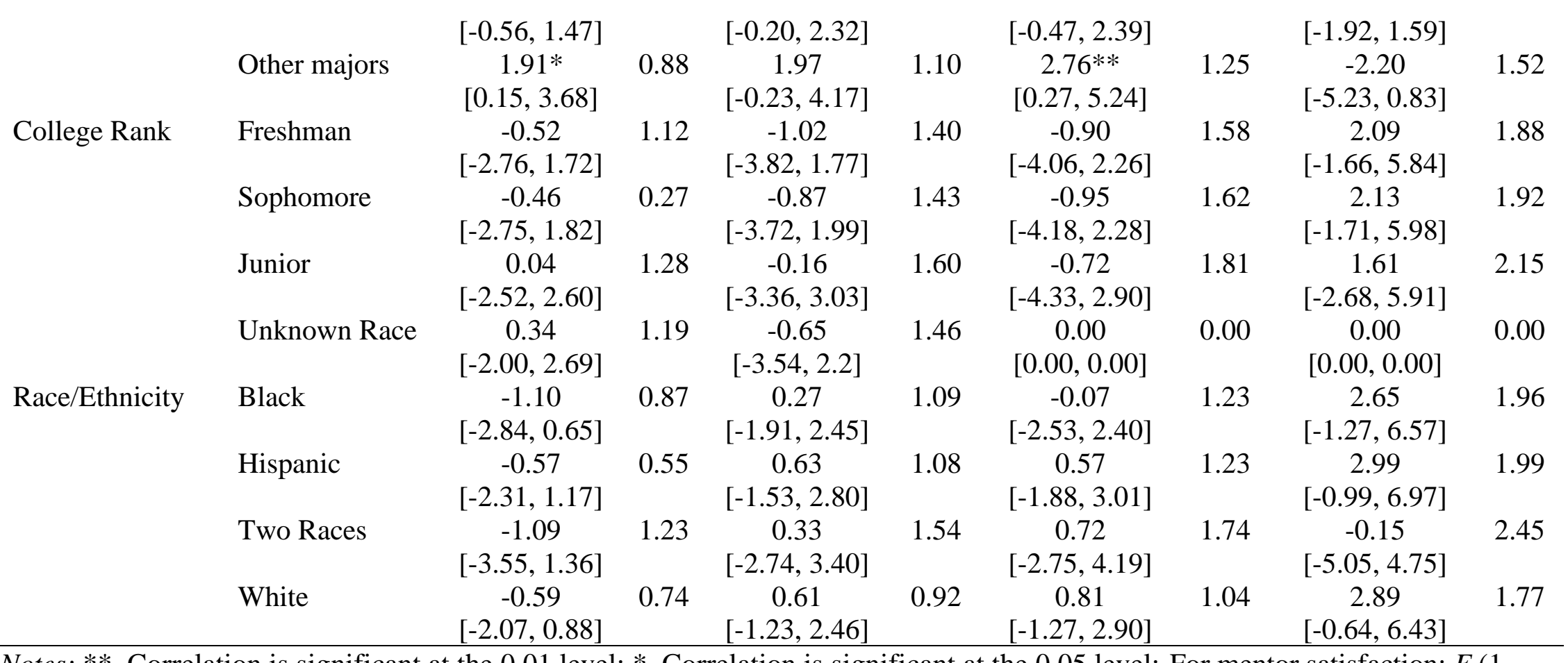

Notes: **. Correlation is significant at the 0.01 level; *. Correlation is significant at the 0.05 level; For mentor satisfaction: $F(1$, $178)=1.96, p=.16, \eta 2=.01$; for psychosocial support: $F(1,178)=1.60, p=.21, \eta 2=.01$; for instrumental support: $F(1,179)=$ $.34, p=.56, \eta 2=.00 ;$ and for mentor diversity: $F(1,154)=2.01, p=.16, \eta 2=.01$; Cohort1 includes fall 2017 and spring 2018 , Cohort 2 include spring 2018 and fall 2018. 
Table 6. Summary of general linear models predicting long-term mentorship-related outcomes from RAP, controlling for background characteristics

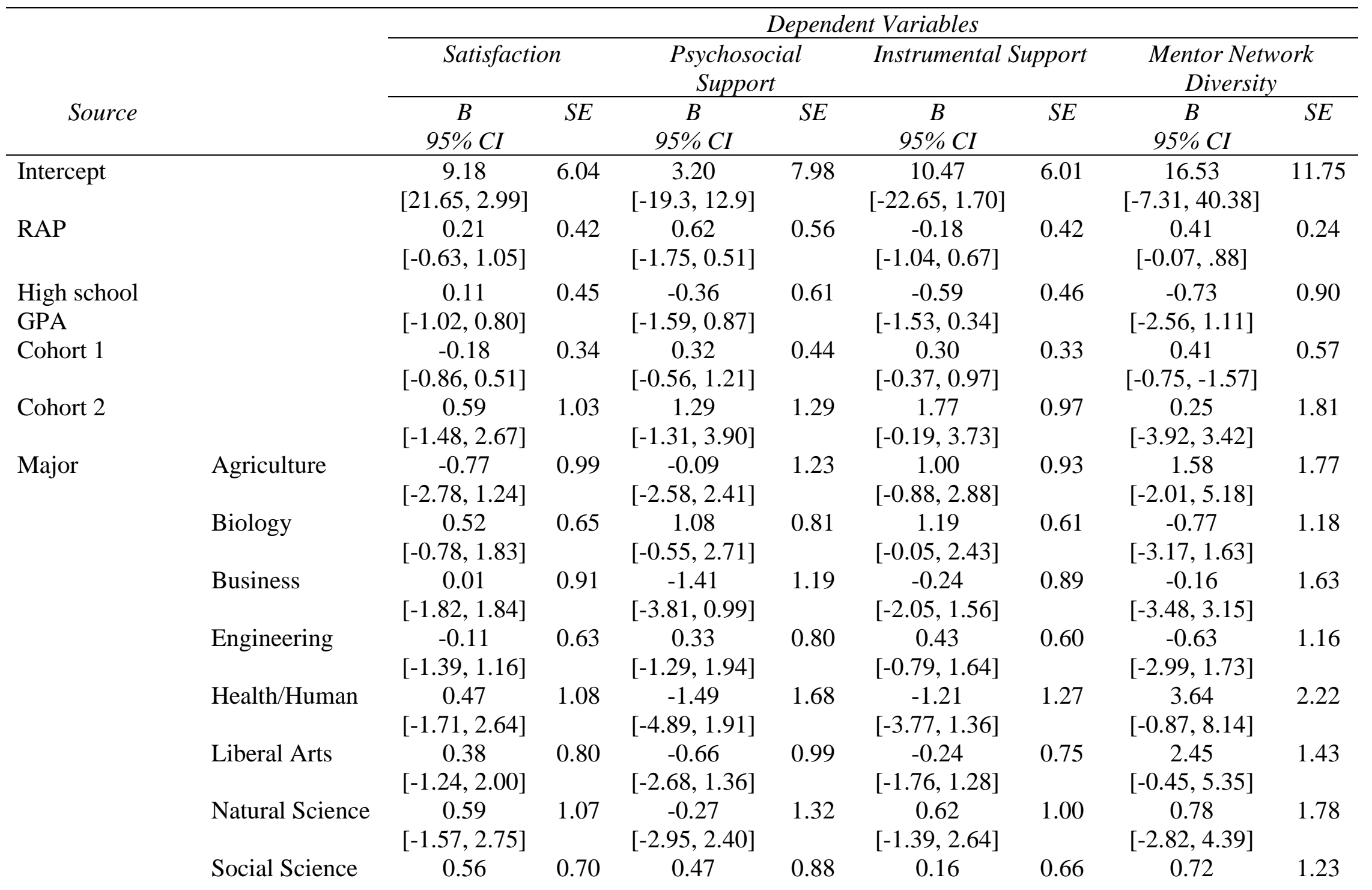




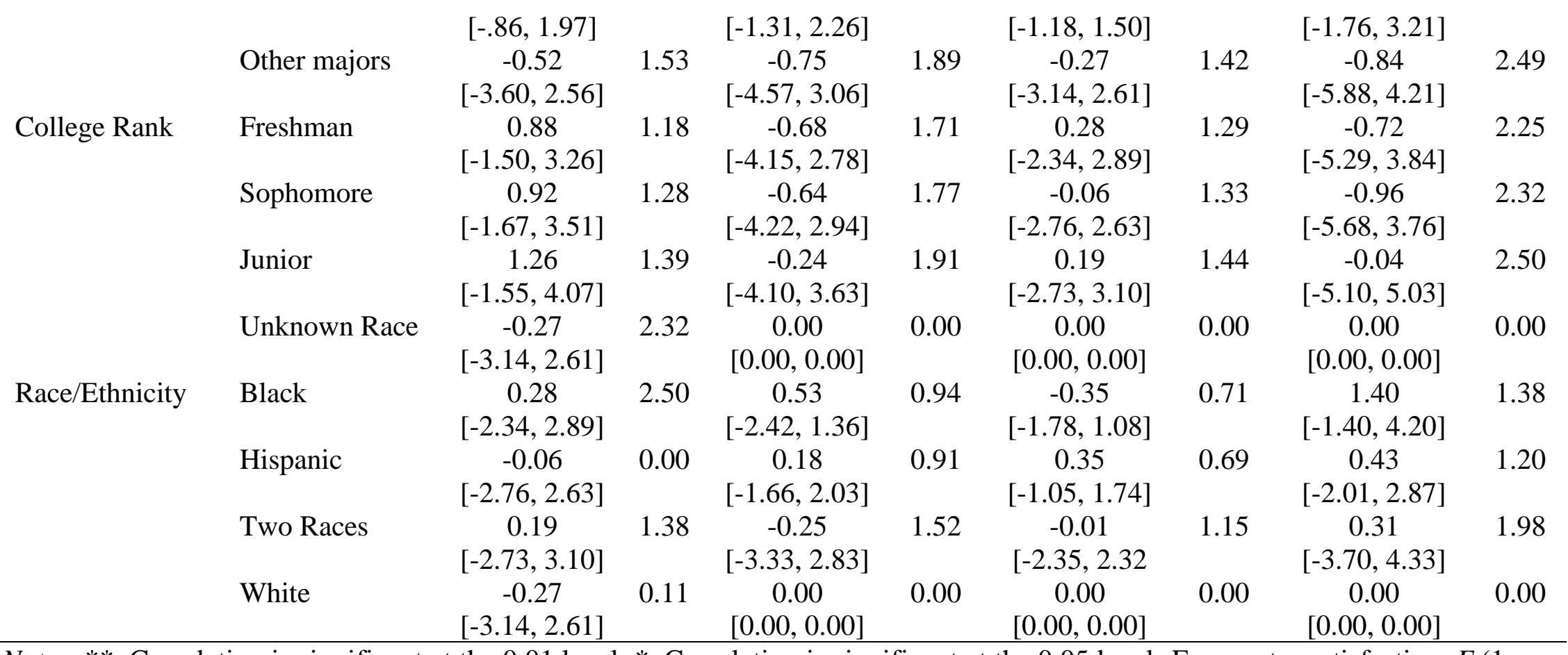

Notes: **. Correlation is significant at the 0.01 level; *. Correlation is significant at the 0.05 level; For mentor satisfaction: $F$ (1, $128)=.73, p=.39, \eta 2=.00$; for psychosocial support: $F(1,126)=1.02, p=.87, \eta 2=.00 ;$ for instrumental support: $F(1,126)=$ $1.75, p=.19, \eta 2=.02$; and for mentor diversity: $F(1,119)=2.89, p=.09, \eta 2=.03$; Cohort1 includes fall 2017 and spring 2018 , Cohort 2 include spring 2018 and fall 2018. 
Table 7. Summary of general linear models predicting short-term persistence intentions-related outcomes from RAP status, controlling for background characteristics

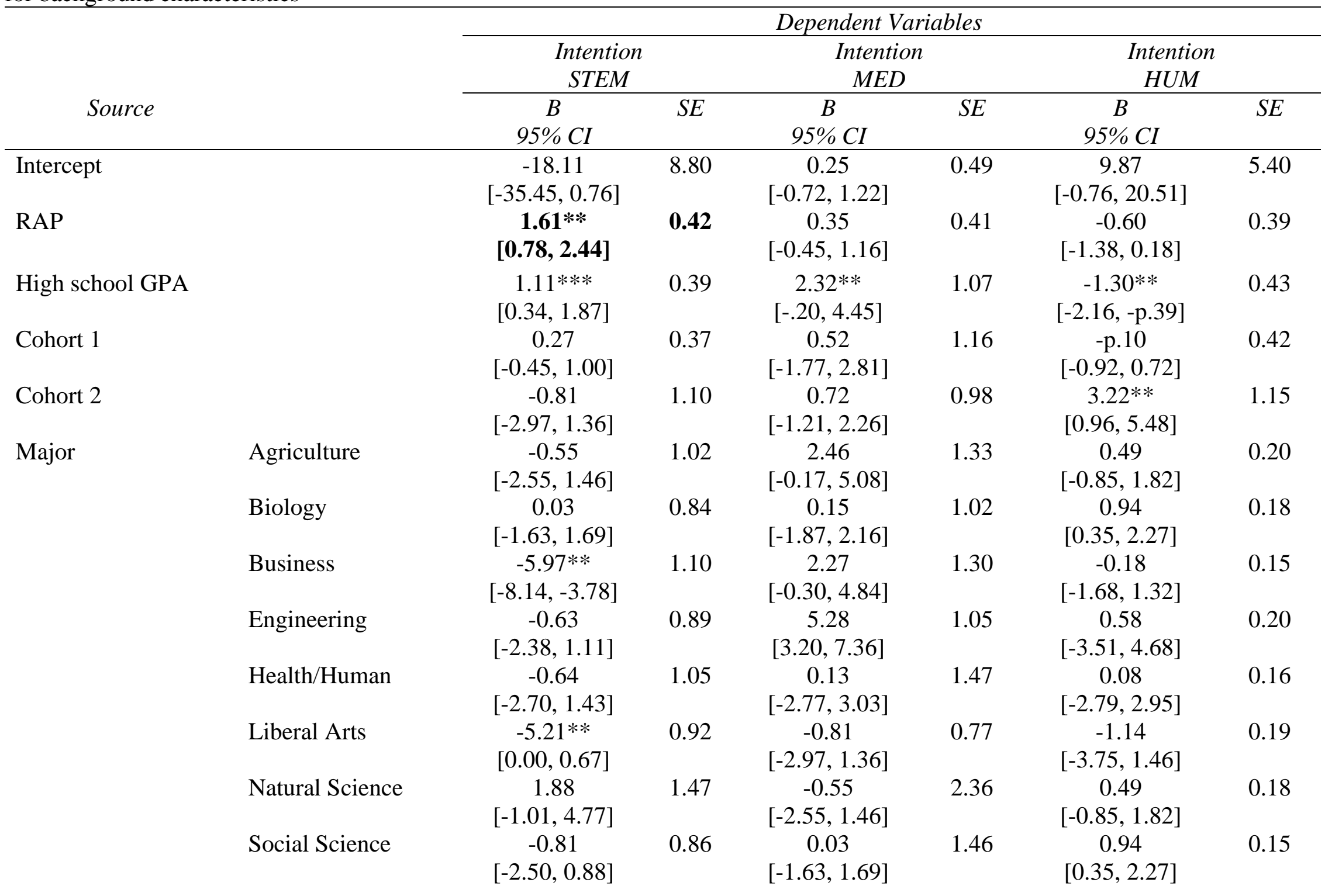




\begin{tabular}{|c|c|c|c|c|c|c|c|}
\hline & Other majors & $\begin{array}{c}0.92 \\
{[-3.20,5.03]}\end{array}$ & 2.08 & $\begin{array}{c}0.15 \\
{[-1.01,1.31]}\end{array}$ & 0.77 & $\begin{array}{c}0.58 \\
{[-3.51,4.68]}\end{array}$ & 0.22 \\
\hline \multirow[t]{4}{*}{ College Rank } & Freshman & $\begin{array}{c}0.15 \\
{[-1.01,1.31]}\end{array}$ & 0.59 & $\begin{array}{c}-0.30 \\
{[-1.46,0.88]}\end{array}$ & 2.36 & $\begin{array}{c}0.08 \\
{[-2.79,2.95]}\end{array}$ & 0.66 \\
\hline & Sophomore & $\begin{array}{c}-0.30 \\
{[-1.46,0.88]}\end{array}$ & 0.59 & $\begin{array}{c}0.38 \\
{[-0.98,1.74]}\end{array}$ & 1.46 & $\begin{array}{c}-1.14 \\
{[-3.75,1.46]}\end{array}$ & 0.67 \\
\hline & Junior & $\begin{array}{c}0.38 \\
{[-0.98,1.74]}\end{array}$ & 0.69 & $\begin{array}{c}5.28 \\
{[3.20,7.36]}\end{array}$ & 1.34 & $\begin{array}{c}0.78 \\
{[-0.74,2.30]}\end{array}$ & 0.77 \\
\hline & Unknown Race & $\begin{array}{c}-2.45 \\
{[-6.57,1.66]}\end{array}$ & 2.09 & $\begin{array}{c}0.13 \\
{[-2.77,3.03]}\end{array}$ & 0.66 & $\begin{array}{c}-0.22 \\
{[-4.42,4.86]}\end{array}$ & 2.36 \\
\hline \multirow[t]{4}{*}{ Race/Ethnicity } & Black & $\begin{array}{c}-1.10 \\
{[-3.56,1.35]}\end{array}$ & 1.25 & $\begin{array}{c}0.92 \\
{[-3.20,5.03]}\end{array}$ & 0.67 & $\begin{array}{c}-1.46 \\
{[-4.34,1.42]}\end{array}$ & 1.46 \\
\hline & Hispanic & $\begin{array}{c}-0.49 \\
{[-2.78,1.80]}\end{array}$ & 1.16 & $\begin{array}{c}0.15 \\
{[-1.01,1.31]}\end{array}$ & 0.59 & $\begin{array}{c}-1.67 \\
{[-4.32,0.97]}\end{array}$ & 1.34 \\
\hline & Two Races & $\begin{array}{c}-1.82 \\
{[-4.37,0.73]}\end{array}$ & 1.29 & $\begin{array}{c}-0.30 \\
{[-1.46,0.88]}\end{array}$ & 0.69 & $\begin{array}{c}-0.20 \\
{[-3.06,2.66]}\end{array}$ & 1.45 \\
\hline & White & $\begin{array}{c}-1.54 \\
{[-3.35,0.26]}\end{array}$ & 0.91 & $\begin{array}{c}0.38 \\
{[-0.98,1.74]}\end{array}$ & 1.11 & $\begin{array}{c}-2.18 * * \\
{[-4.22,-0.15]}\end{array}$ & 1.03 \\
\hline
\end{tabular}

Notes: **. Correlation is significant at the 0.01 level; *. Correlation is significant at the 0.05 level; For STEM: $F(1,253)=4.89, p$

$<.05, \eta 2=.02$; for MED: $F(1,255)=.75, p=.38, \eta 2=.00$; and for HUM: $F(1,253)=2.31, p=.13, \eta 2=.01$; Cohort 1 includes fall 2017 and spring 2018, Cohort 2 include spring 2018 and fall 2018. 
Table 8. Summary of general linear models predicting long-term persistence intentions-related and academic performance outcomes from RAP status, controlling for background characteristics

\begin{tabular}{|c|c|c|c|c|c|c|c|c|c|}
\hline \multirow[b]{3}{*}{ Source } & & \multicolumn{8}{|c|}{ Dependent Variables } \\
\hline & & \multicolumn{2}{|c|}{ Cumulative GPA } & \multicolumn{2}{|c|}{$\begin{array}{c}\text { Intention } \\
\text { STEM } \\
\end{array}$} & \multicolumn{2}{|c|}{$\begin{array}{c}\text { Intention } \\
M E D\end{array}$} & \multicolumn{2}{|c|}{$\begin{array}{c}\text { Intention } \\
\text { HUM }\end{array}$} \\
\hline & & $\begin{array}{c}B \\
95 \% C I\end{array}$ & $S E$ & $\begin{array}{c}B \\
95 \% C I\end{array}$ & $S E$ & $\begin{array}{c}B \\
95 \% C I\end{array}$ & $S E$ & $\begin{array}{c}B \\
95 \% C I\end{array}$ & $S E$ \\
\hline Intercept & & $\begin{array}{c}3.96 \\
{[.81,7.10]}\end{array}$ & 1.60 & $\begin{array}{c}-5.88 \\
{[6.12,14.76]}\end{array}$ & 10.25 & $\begin{array}{c}-12.72 \\
{[-27.74,2.31]}\end{array}$ & 7.61 & $\begin{array}{c}22.62 \\
{[.55,42.68]}\end{array}$ & 5.40 \\
\hline RAP & & $\begin{array}{c}0.14 * \\
{[0.02,0.26]}\end{array}$ & 0.06 & $\begin{array}{c}1.05 * \\
{[0.17,1.94]}\end{array}$ & 0.45 & $\begin{array}{c}0.76 \\
{[-0.43,1.94]}\end{array}$ & 0.60 & $\begin{array}{c}-0.13 \\
{[-0.94,0.68]}\end{array}$ & 0.41 \\
\hline $\begin{array}{l}\text { High school } \\
\text { GPA }\end{array}$ & & $\begin{array}{c}0.51 * * \\
{[0.38,0.64]}\end{array}$ & 0.07 & $\begin{array}{c}1.02 * \\
{[-0.00,2.05]}\end{array}$ & 0.52 & $\begin{array}{c}-0.90 \\
{[-2.30,0.50]}\end{array}$ & 0.71 & $\begin{array}{c}0.25 \\
{[-0.72,1.22]}\end{array}$ & 0.49 \\
\hline Cohort 1 & & $\begin{array}{c}0.00 \\
{[-0.13,0.12]}\end{array}$ & 0.06 & $\begin{array}{c}-0.88 \\
{[-1.77,0.00]}\end{array}$ & 0.45 & $\begin{array}{c}0.53 \\
{[-0.69,1.75]}\end{array}$ & 0.62 & $\begin{array}{c}0.13 \\
{[-0.68,0.94]}\end{array}$ & 0.41 \\
\hline Cohort 2 & & $\begin{array}{c}-0.08 \\
{[-0.46,0.31]}\end{array}$ & 0.20 & $\begin{array}{c}-0.17 \\
{[-2.54,2.19]}\end{array}$ & 1.20 & $\begin{array}{c}-0.77 \\
{[-3.72,2.17]}\end{array}$ & 1.49 & $\begin{array}{c}2.32 * * \\
{[-0.20,4.45]}\end{array}$ & 1.07 \\
\hline \multirow[t]{8}{*}{ Major } & Agriculture & $\begin{array}{c}0.01 \\
{[-0.34,0.37]}\end{array}$ & 0.18 & $\begin{array}{c}-0.44 \\
{[-3.00,2.12]}\end{array}$ & 1.30 & $\begin{array}{c}0.49 \\
{[-0.85,1.82]}\end{array}$ & 1.77 & $\begin{array}{c}0.52 \\
{[-1.77,2.81]}\end{array}$ & 1.16 \\
\hline & Biology & $\begin{array}{c}0.26 \\
{[-0.04,0.56]}\end{array}$ & 0.15 & $\begin{array}{c}0.11 \\
{[-2.05,2.28]}\end{array}$ & 1.10 & $\begin{array}{c}0.94 \\
{[0.35,2.27]}\end{array}$ & 3.19 & $\begin{array}{c}0.72 \\
{[-1.21,2.26]}\end{array}$ & 0.98 \\
\hline & Business & $\begin{array}{c}0.30 \\
{[-0.09,0.69]}\end{array}$ & 0.20 & $\begin{array}{c}-3.20 * * \\
{[-6.12,-0.28]}\end{array}$ & 1.48 & $\begin{array}{c}-0.18 \\
{[-1.68,1.32]}\end{array}$ & 0.74 & $\begin{array}{c}2.46 \\
{[-0.17,5.08]}\end{array}$ & 1.33 \\
\hline & Engineering & $\begin{array}{c}0.08 \\
{[-0.23,0.40]}\end{array}$ & 0.16 & $\begin{array}{c}-.45 \\
{[-2.68,1.79]}\end{array}$ & 1.13 & $\begin{array}{c}0.58 \\
{[-3.51,4.68]}\end{array}$ & 0.72 & $\begin{array}{c}0.15 \\
{[-1.87,2.16]}\end{array}$ & 1.02 \\
\hline & Health/Human & $\begin{array}{c}0.26 \\
{[-0.10,0.63]}\end{array}$ & 0.19 & $\begin{array}{c}0.48 \\
{[-2.25,3.21]}\end{array}$ & 1.38 & $\begin{array}{c}0.08 \\
{[-2.79,2.95]}\end{array}$ & 1.77 & $\begin{array}{c}2.27 \\
{[-0.30,4.84]}\end{array}$ & 1.30 \\
\hline & Liberal Arts & $\begin{array}{c}0.34 * \\
{[0.01,0.66]}\end{array}$ & 0.16 & $\begin{array}{c}-5.07 * * \\
{[-7.37,2.76]}\end{array}$ & 1.17 & $\begin{array}{c}-1.14 \\
{[-3.75,1.46]}\end{array}$ & 3.19 & $\begin{array}{c}5.28 \\
{[3.20,7.36]}\end{array}$ & 1.05 \\
\hline & Natural Science & $\begin{array}{c}0.35 \\
{[-0.14,0.84]}\end{array}$ & 0.25 & $\begin{array}{c}1.58 \\
{[-1.67,4.82]}\end{array}$ & 1.64 & $\begin{array}{c}-0.04 \\
{[-2.88,2.80]}\end{array}$ & 0.74 & $\begin{array}{c}0.13 \\
{[-2.77,3.03]}\end{array}$ & 1.47 \\
\hline & Social Science & 0.14 & 0.15 & -0.90 & 1.10 & 0.40 & 0.72 & 3.21 & 1.00 \\
\hline
\end{tabular}




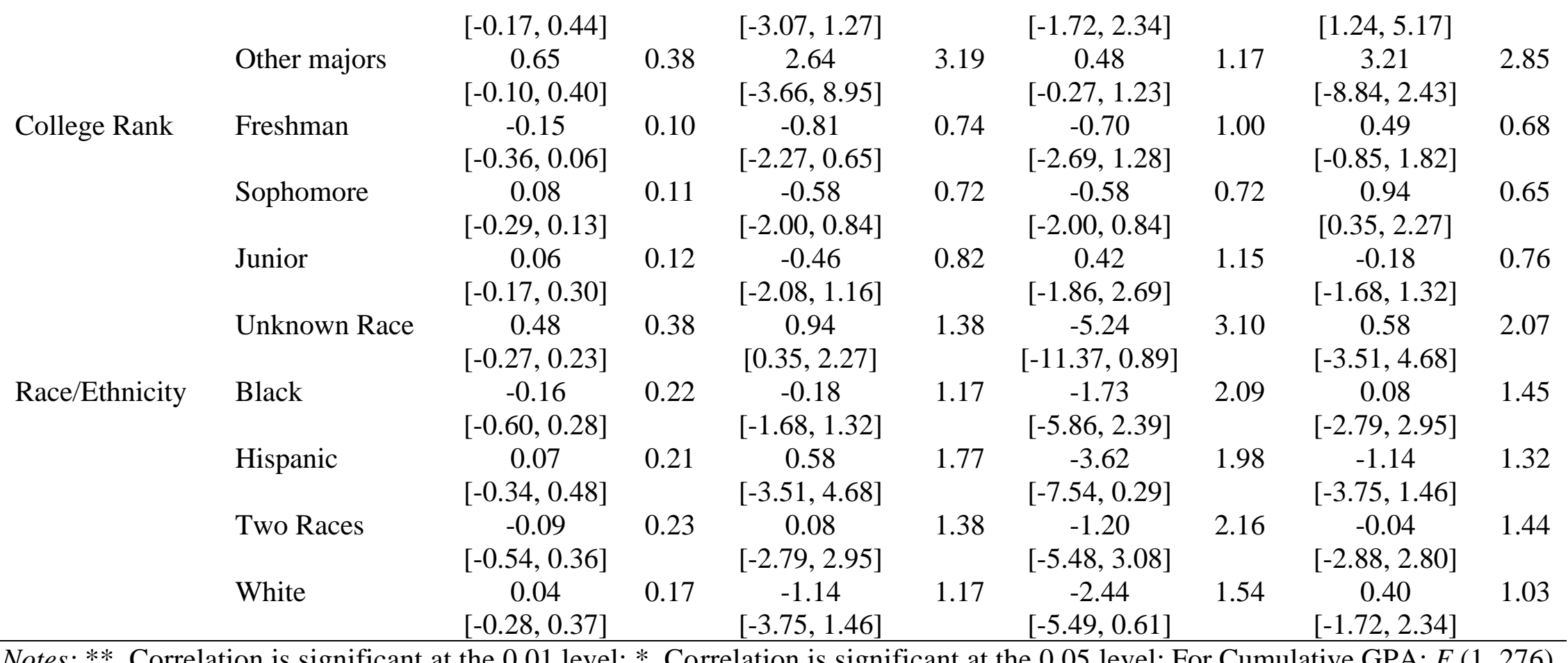

$=5.30, p<.05, \eta 2=.02$; for STEM: $F(1,186)=5.55, p<.05, \eta 2=.03$; for MED: $F(1,184)=1.61, p=.21, \eta 2=.00$; and for

HUM: $F(1,183)=.10, p=.75, \eta 2=.00$; Cohort1 includes fall 2017 and spring 2018, Cohort 2 include spring 2018 and fall 2018. 
Table 9. Summary of general linear models predicting short-term motivational variables from RAP status, controlling for background characteristics

\begin{tabular}{|c|c|c|c|c|c|c|c|}
\hline \multirow{3}{*}{ Source } & & \multicolumn{6}{|c|}{ Dependent Variables } \\
\hline & & \multicolumn{2}{|c|}{ Research self-efficacy } & \multicolumn{2}{|c|}{ Research self-identity } & \multicolumn{2}{|c|}{ Community objective value } \\
\hline & & $\begin{array}{c}B \\
95 \% C I\end{array}$ & $S E$ & $\begin{array}{c}B \\
95 \% C I\end{array}$ & $S E$ & $\begin{array}{c}B \\
95 \% C I\end{array}$ & $S E$ \\
\hline Intercept & & $\begin{array}{c}6.75 \\
{[1.59,15.09]}\end{array}$ & 4.23 & $\begin{array}{c}4.83 \\
{[5.72,15.41]}\end{array}$ & 5.37 & $\begin{array}{c}6.04 \\
{[-1.98,14.05]}\end{array}$ & 4.07 \\
\hline RAP & & $\begin{array}{c}0.55 * * \\
{[0.24,0.87]}\end{array}$ & 0.16 & $\begin{array}{c}1.25 * * \\
{[0.83,1.67]}\end{array}$ & 0.21 & $\begin{array}{c}0.70 * * \\
{[0.38,1.02]}\end{array}$ & 0.16 \\
\hline High school GPA & & $\begin{array}{c}1.11^{*} \\
{[0.34,1.87]}\end{array}$ & 0.39 & $\begin{array}{c}2.32 * * \\
{[-0.20,4.45]}\end{array}$ & 1.07 & $\begin{array}{c}-1.30 * * \\
{[-2.16,-0.39]}\end{array}$ & 0.43 \\
\hline Cohort 1 & & $\begin{array}{c}0.27 \\
{[-0.45,1.00]}\end{array}$ & 0.37 & $\begin{array}{c}0.52 \\
{[-1.77,2.81]}\end{array}$ & 1.16 & $\begin{array}{c}-0.10 \\
{[-0.92,0.72]}\end{array}$ & 0.42 \\
\hline Cohort 2 & & $\begin{array}{c}-0.81 \\
{[-2.97,1.36]}\end{array}$ & 1.10 & $\begin{array}{c}0.72 \\
{[-1.21,2.26]}\end{array}$ & 0.98 & $\begin{array}{c}3.22 * * \\
{[0.96,5.48]}\end{array}$ & 1.15 \\
\hline \multirow[t]{9}{*}{ Major } & Agriculture & $\begin{array}{c}-0.55 \\
{[-2.55,1.46]}\end{array}$ & 1.02 & $\begin{array}{c}2.46 \\
{[-0.17,5.08]}\end{array}$ & 1.33 & $\begin{array}{c}0.49 \\
{[-0.85,1.82]}\end{array}$ & 0.20 \\
\hline & Biology & $\begin{array}{c}0.03 \\
{[-1.63,1.69]}\end{array}$ & 0.84 & $\begin{array}{c}0.15 \\
{[-1.87,2.16]}\end{array}$ & 1.02 & $\begin{array}{c}0.94 \\
{[0.35,2.27]}\end{array}$ & 0.18 \\
\hline & Business & $\begin{array}{c}-5.97 * * \\
{[-8.14,-3.78]}\end{array}$ & 1.10 & $\begin{array}{c}2.27 \\
{[-0.30,4.84]}\end{array}$ & 1.30 & $\begin{array}{c}-0.18 \\
{[-1.68,1.32]}\end{array}$ & 0.15 \\
\hline & Engineering & $\begin{array}{c}-0.63 \\
{[-2.38,1.11]}\end{array}$ & 0.89 & $\begin{array}{c}5.28 \\
{[3.20,7.36]}\end{array}$ & 1.05 & $\begin{array}{c}0.58 \\
{[-3.51,4.68]}\end{array}$ & 0.20 \\
\hline & Health/Human & $\begin{array}{c}-0.64 \\
{[-2.70,1.43]}\end{array}$ & 1.05 & $\begin{array}{c}0.13 \\
{[-2.77,3.03]}\end{array}$ & 1.47 & $\begin{array}{c}0.08 \\
{[-2.79,2.95]}\end{array}$ & 0.16 \\
\hline & Liberal Arts & $\begin{array}{c}0.21^{* *} \\
{[0.00,0.67]}\end{array}$ & 0.92 & $\begin{array}{c}-0.81 \\
{[-2.97,1.36]}\end{array}$ & 0.77 & $\begin{array}{c}-1.14 \\
{[-3.75,1.46]}\end{array}$ & 0.19 \\
\hline & Natural Science & $\begin{array}{c}1.88 \\
{[-1.01,4.77]}\end{array}$ & 1.47 & $\begin{array}{c}-0.55 \\
{[-2.55,1.46]}\end{array}$ & 2.36 & $\begin{array}{c}0.49 \\
{[-0.85,1.82]}\end{array}$ & 0.18 \\
\hline & Social Science & $\begin{array}{c}-0.81 \\
{[-2.50,0.88]}\end{array}$ & 0.86 & $\begin{array}{c}0.03 \\
{[-1.63,1.69]}\end{array}$ & 1.46 & $\begin{array}{c}0.94 \\
{[0.35,2.27]}\end{array}$ & 0.15 \\
\hline & Other majors & 0.92 & 2.08 & 0.15 & 0.77 & 0.58 & 0.22 \\
\hline
\end{tabular}




\begin{tabular}{|c|c|c|c|c|c|c|c|}
\hline \multirow{5}{*}{ College Rank } & & {$[-3.20,5.03]$} & & {$[-1.01,1.31]$} & & {$[-3.51,4.68]$} & \\
\hline & Freshman & $\begin{array}{c}0.15 \\
{[-1.01,1.31]}\end{array}$ & 0.59 & $\begin{array}{c}-0.30 \\
{[-1.46,0.88]}\end{array}$ & 2.36 & $\begin{array}{c}0.08 \\
{[-279 \quad 2.95]}\end{array}$ & 0.66 \\
\hline & Sophomore & $\begin{array}{c}-0.30 \\
{[-1.46,0.88]}\end{array}$ & 0.59 & $\begin{array}{c}0.38 \\
{[-0.98,1.74]}\end{array}$ & 1.46 & $\begin{array}{c}-1.14 \\
{[-3.75,1.46]}\end{array}$ & 0.67 \\
\hline & Junior & $\begin{array}{c}0.38 \\
{[-0.98,1.74]}\end{array}$ & 0.69 & $\begin{array}{c}5.28 \\
{[3.20,7.36]}\end{array}$ & 1.34 & $\begin{array}{c}0.78 \\
{[-0.74,2.30]}\end{array}$ & 0.77 \\
\hline & Unknown Race & $\begin{array}{c}-2.45 \\
{[-6.57,1.66]}\end{array}$ & 2.09 & $\begin{array}{c}0.13 \\
{[-2.77,3.03]}\end{array}$ & 0.66 & $\begin{array}{c}-0.22 \\
{[-4.42,4.86]}\end{array}$ & 2.36 \\
\hline \multirow[t]{4}{*}{ Race/Ethnicity } & Black & $\begin{array}{c}-1.10 \\
{[-3.56,1.35]}\end{array}$ & 1.25 & $\begin{array}{c}0.92 \\
{[-3.20,5.03]}\end{array}$ & 0.67 & $\begin{array}{c}-1.46 \\
{[-4.34,1.42]}\end{array}$ & 1.46 \\
\hline & Hispanic & $\begin{array}{c}-0.49 \\
{[-2.78,1.80]}\end{array}$ & 1.16 & $\begin{array}{c}0.15 \\
{[-1.01,1.31]}\end{array}$ & 0.59 & $\begin{array}{c}-1.67 \\
{[-4.32,0.97]}\end{array}$ & 1.34 \\
\hline & Two Races & $\begin{array}{c}-1.82 \\
{[-4.37,0.73]}\end{array}$ & 1.29 & $\begin{array}{c}-0.30 \\
{[-1.46,0.88]}\end{array}$ & 0.69 & $\begin{array}{c}-0.20 \\
{[-3.06,2.66]}\end{array}$ & 1.45 \\
\hline & White & $\begin{array}{c}-1.54 \\
{[-3.35,0.26]}\end{array}$ & 0.91 & $\begin{array}{c}0.38 \\
{[-0.98,1.74]}\end{array}$ & 1.11 & $\begin{array}{c}-2.18 * * \\
{[-4.22,-0.15]}\end{array}$ & 1.03 \\
\hline
\end{tabular}

Notes: **. Correlation is significant at the 0.01 level; *. Correlation is significant at the 0.05 level; For research self-efficacy: $F$ (1, $258)=11.77, p<.01, \eta 2=.05 ;$ for research self-identity: $F(1,257)=33.71, p<.01, \eta 2=.13$; and for community objective value: $F$ $(1,258)=18.33, p<.01, \eta 2=.07$; Cohort1 includes fall 2017 and spring 2018, Cohort 2 include spring 2018 and fall 2018. 
Table 10. Summary of general linear models predicting long-term motivational variables from RAP status, controlling for background characteristics

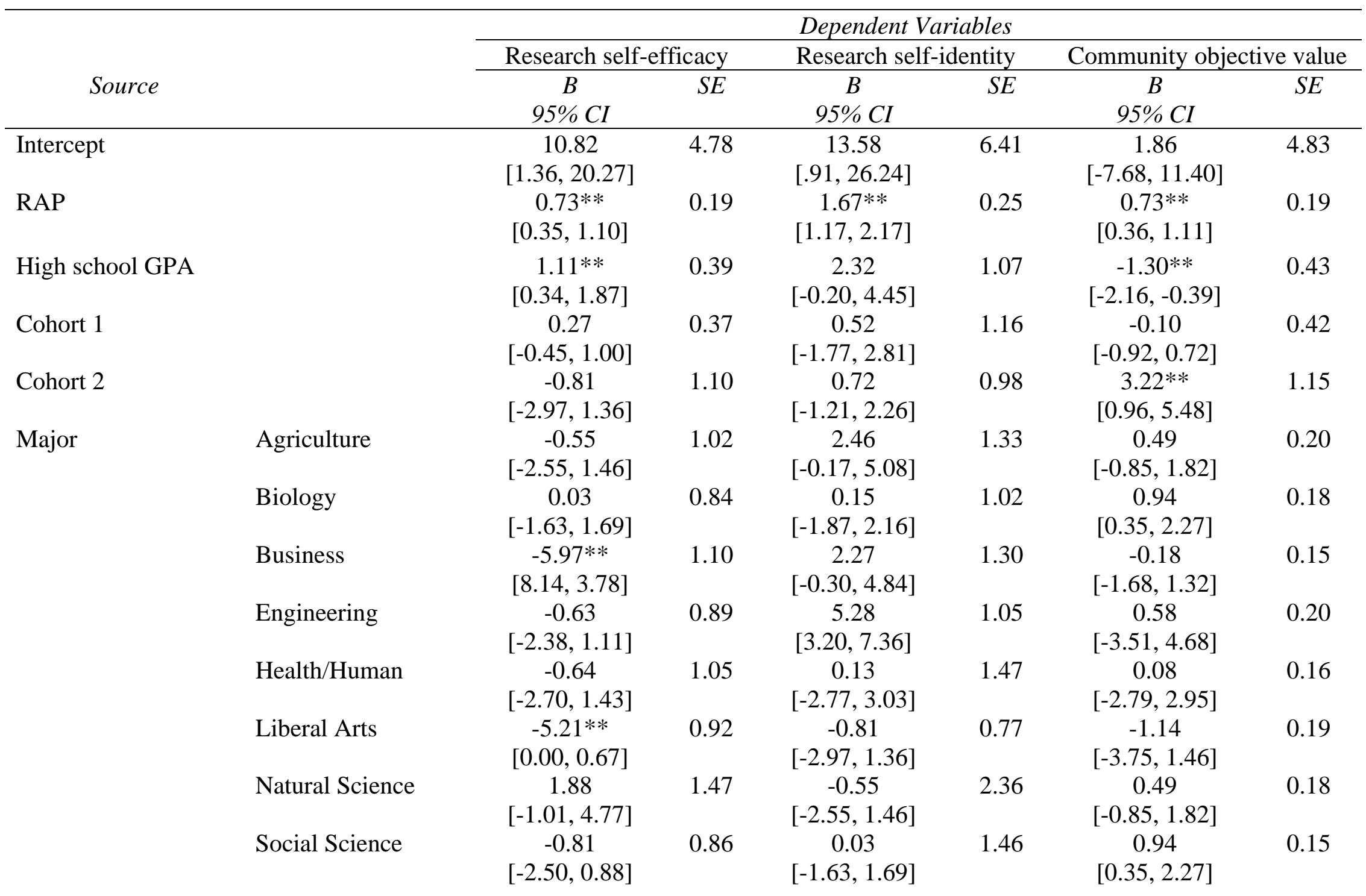




\begin{tabular}{|c|c|c|c|c|c|c|c|}
\hline & Other majors & $\begin{array}{c}0.92 \\
{[-3.20,5.03]}\end{array}$ & 2.08 & $\begin{array}{c}0.15 \\
{[-1.01,1.31]}\end{array}$ & 0.77 & $\begin{array}{c}0.58 \\
{[-3.51,4.68]}\end{array}$ & 0.22 \\
\hline \multirow[t]{4}{*}{ College Rank } & Freshman & $\begin{array}{c}0.15 \\
{[-1.01,1.31]}\end{array}$ & 0.59 & $\begin{array}{c}-0.30 \\
{[-1.46,0.88]}\end{array}$ & 2.36 & $\begin{array}{c}0.08 \\
{[-2.79,2.95]}\end{array}$ & 0.66 \\
\hline & Sophomore & $\begin{array}{c}-0.30 \\
{[-1.46,0.88]}\end{array}$ & 0.59 & $\begin{array}{c}0.38 \\
{[-0.98,1.74]}\end{array}$ & 1.46 & $\begin{array}{c}-1.14 \\
{[-3.75,1.46]}\end{array}$ & 0.67 \\
\hline & Junior & $\begin{array}{c}0.38 \\
{[-0.98,1.74]}\end{array}$ & 0.69 & $\begin{array}{c}5.28 \\
{[3.20,7.36]}\end{array}$ & 1.34 & $\begin{array}{c}0.78 \\
{[-0.74,2.30]}\end{array}$ & 0.77 \\
\hline & Unknown Race & $\begin{array}{c}-2.45 \\
{[-6.57,1.66]}\end{array}$ & 2.09 & $\begin{array}{c}0.13 \\
{[-2.77,3.03]}\end{array}$ & 0.66 & $\begin{array}{c}-0.22 \\
{[-4.42,4.86]}\end{array}$ & 2.36 \\
\hline \multirow[t]{4}{*}{ Race/Ethnicity } & Black & $\begin{array}{c}-1.10 \\
{[-3.56,1.35]}\end{array}$ & 1.25 & $\begin{array}{c}0.92 \\
{[-3.20,5.03]}\end{array}$ & 0.67 & $\begin{array}{c}-1.46 \\
{[-4.34,1.42]}\end{array}$ & 1.46 \\
\hline & Hispanic & $\begin{array}{c}-0.49 \\
{[-2.78,1.80]}\end{array}$ & 1.16 & $\begin{array}{c}0.15 \\
{[-1.01,1.31]}\end{array}$ & 0.59 & $\begin{array}{c}-1.67 \\
{[-4.32,0.97]}\end{array}$ & 1.34 \\
\hline & Two Races & $\begin{array}{c}-1.82 \\
{[-4.37,0.73]}\end{array}$ & 1.29 & $\begin{array}{c}-0.30 \\
{[-1.46,0.88]}\end{array}$ & 0.69 & $\begin{array}{c}-0.20 \\
{[-3.06,2.66]}\end{array}$ & 1.45 \\
\hline & White & $\begin{array}{c}-1.54 \\
{[-3.35,0.26]}\end{array}$ & 0.91 & $\begin{array}{c}0.38 \\
{[-0.98,1.74]}\end{array}$ & 1.11 & $\begin{array}{c}-2.18 * * \\
{[-4.22,-0.15]}\end{array}$ & 1.03 \\
\hline
\end{tabular}

Notes: **. Correlation is significant at the 0.01 level; *. Correlation is significant at the 0.05 level; For research self-efficacy: $F(1$, $186)=14.63, p<.01, \eta 2=.08$; for research self-identity: $F(1,186)=43.47, p<.01, \eta 2=.21$; and for community objective value: $F$ $(1,184)=14.66, p<.01, \eta 2=.08$; Cohort1 includes fall 2017 and spring 2018, Cohort 2 include spring 2018 and fall 2018. 
Table 11. Summary of regression-based mediation models assessing the total and indirect effect of RAP status on performance and persistence outcomes through motivational variables, controlling for background characteristic

\begin{tabular}{|c|c|c|c|c|c|c|c|c|}
\hline \multirow[b]{3}{*}{$\begin{array}{c}\text { Dependent Variable } \\
\text { (Short-term) }\end{array}$} & \multirow{2}{*}{\multicolumn{2}{|c|}{ Total effect }} & \multicolumn{6}{|c|}{ Short-term Mediators } \\
\hline & & & Research self- & icacy & \multicolumn{2}{|c|}{ Research-identity } & \multicolumn{2}{|c|}{$\begin{array}{l}\text { Community objective } \\
\text { value }\end{array}$} \\
\hline & $\begin{array}{c}B \\
{[C I]}\end{array}$ & $S E$ & $\begin{array}{c}B \\
{[C I]}\end{array}$ & $S E$ & $\begin{array}{c}B \\
{[C I]}\end{array}$ & $S E$ & $\begin{array}{c}B \\
{[C I]}\end{array}$ & $S E$ \\
\hline Intention-STEM & $\begin{array}{c}1.61 * \\
{[0.78,2.44]}\end{array}$ & 0.42 & $\begin{array}{c}0.09 \\
{[-0.11,0.33]}\end{array}$ & 0.11 & $\begin{array}{c}0.37 \\
{[-0.00,0.79]}\end{array}$ & 0.20 & $\begin{array}{c}0.36 * \\
{[0.05,0.76]}\end{array}$ & $\mathbf{0 . 1 8}$ \\
\hline Intention-MED & $\begin{array}{c}0.38 \\
{[-0.59,1.36]}\end{array}$ & 0.50 & $\begin{array}{c}-0.01 \\
{[-0.22,0.22]}\end{array}$ & 0.11 & $\begin{array}{c}0.11 \\
{[-0.37,0.59]}\end{array}$ & 0.24 & $\begin{array}{c}0.43 \\
{[-0.08,0.88]}\end{array}$ & 0.20 \\
\hline \multirow[t]{3}{*}{ Intention-HUM } & $\begin{array}{c}-0.73 \\
{[-1.49,0.03]}\end{array}$ & 0.39 & $\begin{array}{c}0.05 \\
{[-0.11,0.25]}\end{array}$ & 0.09 & $\begin{array}{c}0.38 * \\
{[0.06,0.77]}\end{array}$ & 0.18 & $\begin{array}{c}0.07 \\
{[-0.22,0.36]}\end{array}$ & 0.14 \\
\hline & & & \multicolumn{6}{|c|}{ Long-term Mediators } \\
\hline & Total effe & & Research self & icacy & Research-i & & $\begin{array}{r}\text { Community } o \\
\text { value }\end{array}$ & ctive \\
\hline $\begin{array}{c}\text { Dependent Variable } \\
\text { (Long-term) }\end{array}$ & $\begin{array}{c}B \\
{[C I]}\end{array}$ & $S E$ & $\begin{array}{c}B \\
{[C I]}\end{array}$ & $S E$ & $\begin{array}{c}B \\
{[C I]}\end{array}$ & $S E$ & $\begin{array}{c}B \\
{[C I]}\end{array}$ & $S E$ \\
\hline Intention-STEM & $\begin{array}{c}1.05 * \\
{[0.17,1.94]}\end{array}$ & 0.45 & $\begin{array}{c}-0.04 \\
{[-0.32,0.23]}\end{array}$ & 0.13 & $\begin{array}{c}1.15 * \\
{[0.49,1.93]}\end{array}$ & 0.36 & $\begin{array}{c}0.36 \\
{[-0.02,0.79]}\end{array}$ & 0.20 \\
\hline Intention-MED & $\begin{array}{c}0.33 \\
{[-0.79,1.46]}\end{array}$ & 0.57 & $\begin{array}{c}-0.23 \\
{[-0.64,0.05]}\end{array}$ & 0.18 & $\begin{array}{c}0.24 \\
{[-0.49,1.03]}\end{array}$ & 0.38 & $\begin{array}{c}0.58 \\
{[0.17,1.13]}\end{array}$ & 0.25 \\
\hline Intention-HUM & $\begin{array}{c}-0.51 \\
{[-1.43,0.41]}\end{array}$ & 0.47 & $\begin{array}{c}0.15 \\
{[-0.08,0.45]}\end{array}$ & 0.13 & $\begin{array}{c}0.05 \\
{[-0.60,0.72]}\end{array}$ & 0.33 & $\begin{array}{c}0.09 \\
{[-0.24,0.46]}\end{array}$ & 0.18 \\
\hline Cumulative GPA & $\begin{array}{c}0.14 * \\
{[0.02,0.26]}\end{array}$ & 0.06 & $\begin{array}{c}-0.02 \\
{[-0.08,0.01]}\end{array}$ & 0.02 & $\begin{array}{c}0.04 \\
{[-0.05,0.06]}\end{array}$ & 0.05 & $\begin{array}{c}0.01 \\
{[-0.05,0.06]}\end{array}$ & 0.03 \\
\hline
\end{tabular}

\footnotetext{
Notes: * means significant indirect effects; number of bootstrapped in the regression analysis: 10,000 iterations.
} 
Table 12. Summary of general linear models predicting long-term persistence intentions-related and academic performance outcomes from motivational variables, controlling for background characteristics

\begin{tabular}{|c|c|c|c|c|c|c|c|c|}
\hline \multirow[b]{3}{*}{ Independent variables } & \multicolumn{8}{|c|}{ Dependent variables } \\
\hline & \multicolumn{2}{|c|}{ STEM intention } & \multicolumn{2}{|c|}{ HUM intention } & \multicolumn{2}{|c|}{ MED intention } & \multicolumn{2}{|c|}{$G P A$} \\
\hline & $\begin{array}{c}B \\
{[C I]}\end{array}$ & $S E$ & $\begin{array}{c}B \\
{[C I]}\end{array}$ & $S E$ & $\begin{array}{c}B \\
{[C I]}\end{array}$ & $S E$ & $\begin{array}{c}B \\
{[C I]}\end{array}$ & $S E$ \\
\hline $\begin{array}{l}\text { Research self-efficacy } \\
\text { T2 }\end{array}$ & $\begin{array}{c}0.60 * * \\
{[0.23,0.97]}\end{array}$ & 0.19 & $\begin{array}{c}0.28 \\
{[-0.07,0.64]}\end{array}$ & 0.18 & $\begin{array}{c}-0.16 \\
{[-0.60,0.27]}\end{array}$ & 0.22 & $\begin{array}{c}-0.01 \\
{[-0.06,0.05]}\end{array}$ & 0.03 \\
\hline $\begin{array}{l}\text { Research identity } \\
\mathrm{T} 2\end{array}$ & $\begin{array}{c}0.81 * * \\
{[0.57,1.05]}\end{array}$ & 0.12 & $\begin{array}{c}0.05 \\
{[-0.20,0.30]}\end{array}$ & 0.13 & $\begin{array}{c}0.21 \\
{[-0.09,0.50]}\end{array}$ & 0.15 & $\begin{array}{c}0.02 \\
{[-0.02,0.06]}\end{array}$ & 0.19 \\
\hline $\begin{array}{l}\text { Community objective } \\
\text { values } \mathrm{T} 2\end{array}$ & $\begin{array}{c}0.90 * * \\
{[0.54,127]}\end{array}$ & 0.18 & $\begin{array}{c}0.10 \\
{[-0.27,0.47]}\end{array}$ & 0.19 & $\begin{array}{c}0.53 * \\
{[0.10,0.96]}\end{array}$ & 0.22 & $\begin{array}{c}0.04 \\
{[-0.02,0.09]}\end{array}$ & 0.03 \\
\hline
\end{tabular}

Notes: **. Correlation is significant at the 0.01 level; *. Correlation is significant at the 0.05 level 
Table 13. Summary of general linear models and logistic regression predicting expected variables from RAP status, controlling for background characteristic

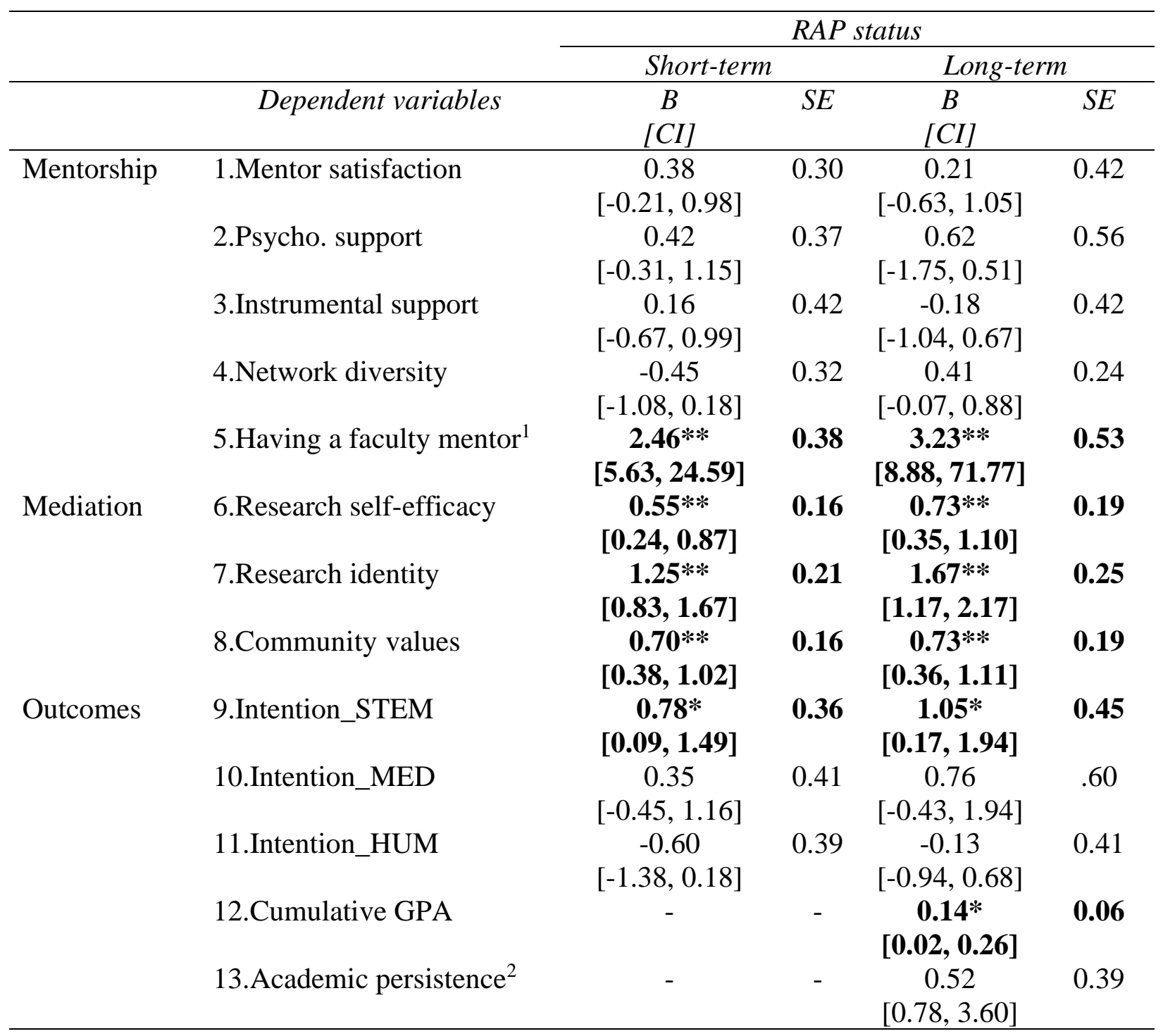

Notes: **. Correlation is significant at the 0.01 level; *. Correlation is significant at the 0.05

level. ${ }^{1,2}$ Having a faculty mentor and Academic persistence variables are categorical variables. 


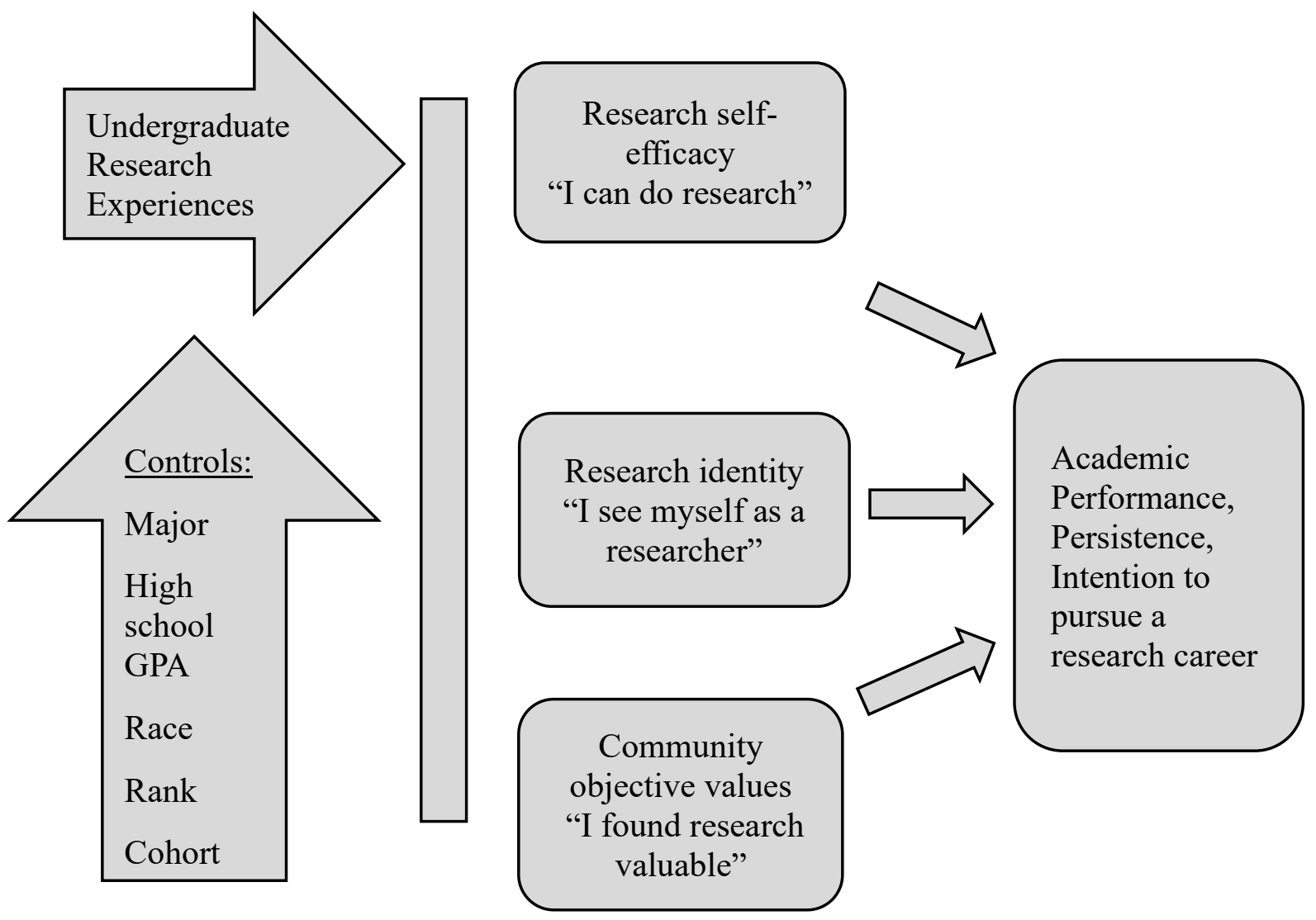

Figure 1. Tripartite Integration Model of Social Influence (TIMSI) 

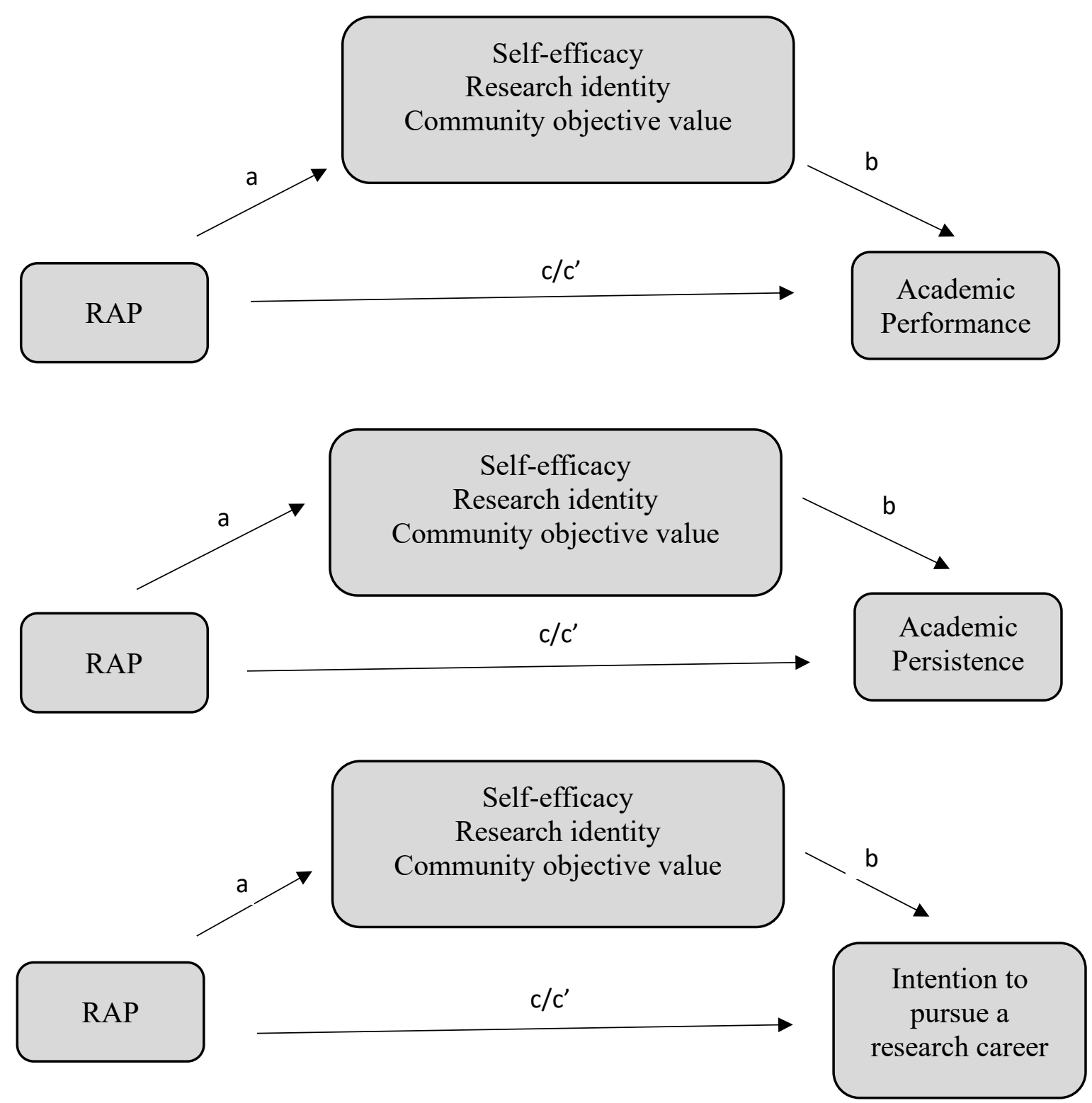

Figure 2. The mediation impact of TIMSI components on the relationship between RAP and its expected outcomes 


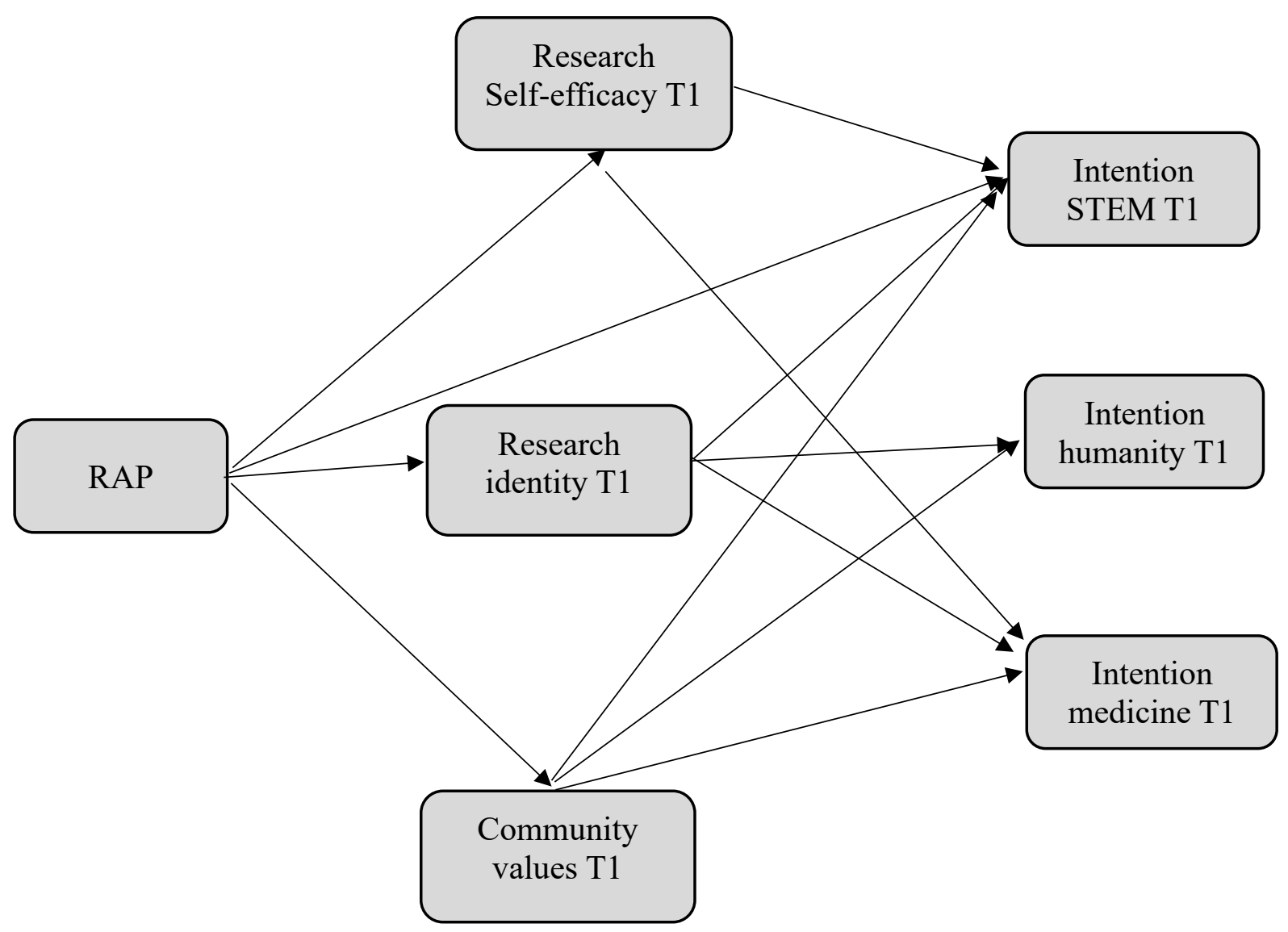

Figure 3. Short-term significant relationships between RAP status, TIMSI components, and students' expected outcomes

Significant indirect effects: RAP $\rightarrow$ Value $\rightarrow$ STEM, and RAP $\rightarrow$ Identity $\rightarrow$ humanity 


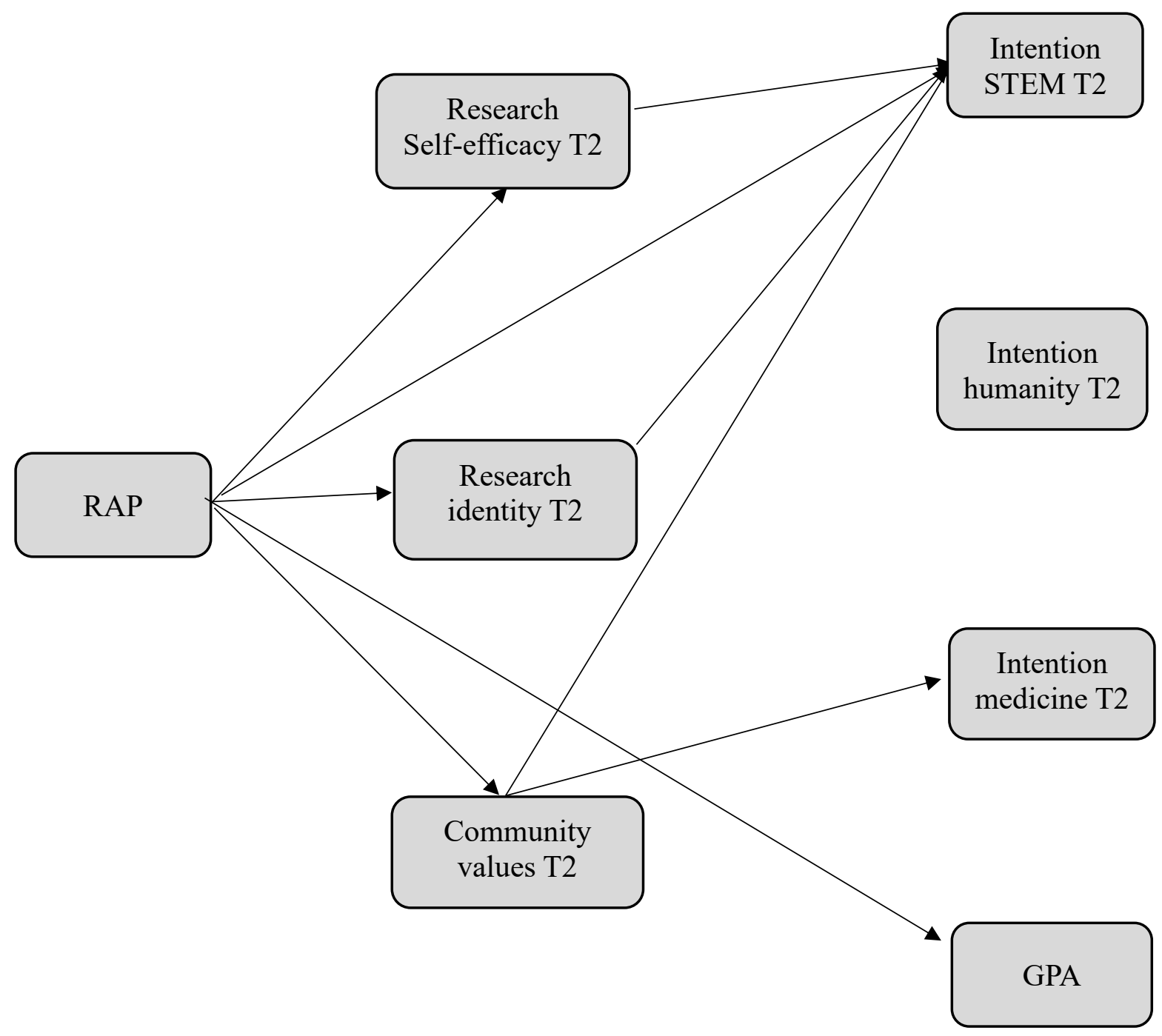

Figure 4. Long-term significant relationships between RAP status, TIMSI components, and students' expected outcomes.

Significant indirect effect: RAP $\rightarrow$ identity $\rightarrow$ STEM 